\section{EFFECT OF OXYGEN} TRANSPORT AND RESISTIVITY OF THE ENVIRONMENT ON THE CORROSION OF STEEL

\section{E. Escalante \\ T. Oka \\ U. Bertocci}

U.S. DEPARTMENT OF COMMERCE Natlonal Institute of Standards and Tochnology

Materials Sclence and Englneering Laboratory

Galthereburg, MD 20899

Final Report

U.S. DEPARTMENT OF COMMERCE Robort A. Mosbacher, secretary MATIONAL INSTIUUTE OF STANDARDS AND TECHNOLOQY

John W. Lyone, Director

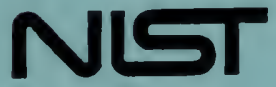





\section{EFFECT OF OXYGEN TRANSPORT AND RESISTIVITY OF THE ENVIRONMENT ON THE CORROSION OF STEEL}

\section{E. Escalante \\ T. Oka \\ U. Bertocci}

U.S. DEPARTMENT OF COMMERCE Natlonal Instltute of Standards and Technology Materlals Sclence and Englneering Laboratory

Galthersburg, MD 20899

September 1990

Final Report

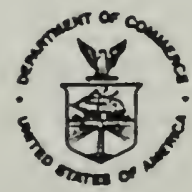

John W. Lyons, Director 



\section{TABLE OF CONTENTS}

\section{Page}

Table of Contents

i i i

List of Figures

v

List of Tables

vii

Abstract

Introduction

1

Experimental

2

Measurements of the Transport Conditions

4

Corrosion Rate Measurements

8

Distribution of Corrosion Over the Surface

Discussion

10

Conclusions

13

References

14 



\section{LIST OF FIGURES}

Figure

Title

Page

1. Schematic drawing of the cell.

2. Conductivity of various media.

3. Calculated current density for chronoamperometric transient on a cylindrical electrode.

4. Chronoamperometric transients. Cells 1, 2, 3 and 4.

5. Chronoamperometric transients. Cells 5, 6, 7 and 8 .

6. Chronoamperometric transients. Cells 9, 10, 11, and 12 . 20

7. Conductivity vs,. diffusion coefficient in sand and $0.0035 \% \mathrm{NaCl}$.

8. Examples of EIS results. Absolute $Z$ vs. frequency. 22

9. Examples of EIS results. Phase angle vs. frequency. 23

10. Measured electrode admittance and corrosion potential 24 for Cells 1, 2, 3, and 4.

11. Measured electrode admittance and corrosion potential for Cells $5,6,7$, and 8 .

12. Measured electrode admittance and corrosion potential for Cells 9, 10, 11, and 12.

13. Comparison between weight loss data and EIS data.

14. Examples of profilometer traces.

a) $0.35 \% \mathrm{NaCl}$. Aqueous solution

b) $3.5 \% \mathrm{NaCl}$. Sand.

15. Corrosion rate vs. effective diffusion coefficient in the media.

29

16. Corrosion rate vs. conductivity of the media.

17. Relationship between corrosion rate and corrosion potential in aqueous solution and in sand.

18. Small and large scale surface roughness as a function of solution conductivity. 



\section{LIST OF TABLES}

Table

Title

Page

$1 \quad$ Properties of the Corrosive Media

3

II Size Characterization of the Sand 4

III Constants Used in Calculating Transient Current 6

IV Diffusion Coefficient and Oxygen Concentration 6

Values Calculated from Experimental Data

Obtained in Aqueous Solutions

V Diffusion Coefficient and Oxygen Concentration

Values Calculated from Experimental Data

Obtained in Aqueous Solutions With Sand

VI Average Admitance and Average Corrosion Rate Values For the Cells

VII Characterization of the Surface Morphology of the Steel After Exposure In Aqueous and Sand Environments 



\title{
EFFECT OF OXYGEN TRANSPORT AND RESISTIVITY OF THE ENVIRONMENT ON THE CORROSION OF STEEL
}

\author{
E. Escalante, T. Oka", and U. Bertocci \\ National Institute of Standards and Technology \\ Gaithersburg, MD 20899
}

\section{ABSTRACT}

This study is directed at investigating the rate of corrosion and its spatial distribution, that develop under conditions where transport of oxygen and conductivity of the environment are controlled over a wide range, including low conductivity as expected in the Yucca Mountain environment. The results indicate that the corrosion rate of steel is directly related to the rate of oxygen transport over several orders of magnitude, and increasing conductivity by one order of magnitude increases corrosion rate by a factor of two or three. Of greater significance is the result that indicates that as conductivity of the environment decreases, and corrosion rate decreases, the degree of localized attack increases.

\section{INTRODUCTION}

The United States faces the problem of the disposal of nuclear waste generated by our nuclear energy facilities, both military and civilian. Presently, the Department of Energy (DOE) bears responsibility for developing a suitable means of encapsulating and burying this waste. At this time, the DOE proposes to use a metallic canister approximately $4 \mathrm{~m}$ high an $\mathrm{m}$ in diameter with a 1 $\mathrm{cm}$ wall thickness [1]. The plan calls for burial of thousands of these canisters, containing nuclear waste, in Nevada at Yucca Mountain [2].

Much of the corrosion research conducted in this effort, under the auspices of DOE, assumes that general corrosion will be uniformly distributed over the surface of the canister [3-6]. Based on the assumption of uniformly distributed corrosion, the DOE expects no corrosion induced penetration of the

\footnotetext{
- Nippon Steel Corporation, Tokyo, Japan
} 
metallic canister for thousands of years [1]. If corrosion is not uniform, however, penetration of the canister could occur earlier than expected [7]. Generally, the DOE sponsored corrosion research has been conducted under environmental conditions of high oxygen transport and high conductivity, and no attempts have been made to study the unevenness of general corrosion rates over the surface.

Most studies on corrosion of High Level Waste container materials have been carried out in aqueous solutions in which mass transport occurs easily and conductivity of the electrolyte is high. However, it is important to consider the effect of low conductivity, as expected in the tuff environment of Yucca Mountain, on the corrosion of metals

The objective of this study was to examine how the overall rate of corrosion and its distribution vary when transport of oxygen and conductivity of the environment are controlled over a wide range.

\section{EXPERIMENTAL}

Small steel coupons $(2 \times 2.5 \mathrm{~cm})$ were immersed in corrosive media of different transport properties and conductivity, and the corrosion rate of each coupon was measured periodically. Conductivity was controlled principally by varying the salt concentration, and mass transport was controlled by mixing the solutions with an inert filler. The cell design is illustrated in Fig. 1, which shows the relative placement of the electrodes. Beside the steel coupons, there is a gold cylindrical electrode located at the center of the cell and, against the cell wall, an AISI Type 304 stainless steel sheet counter electrode (CE). The steel coupons, during the corrosion measurements, and the gold electrode, during the transport measurements, served as working electrodes (WE). When measurements were performed, a reference electrode (RE) was placed between the gold electrode and the CE. The cell was kept in an environmental chamber at constant temperature $\left(23^{\circ} \mathrm{C}\right)$ and at $100 \%$ relative humidity, and moisture-saturated air was circulated in order to maintain the oxygen concentration constant.

The coupons, made of low carbon AISI 1020, were sheared from 0.61 $\mathrm{mm}$ sheet, and their surface was prepared by abrading with 240 grit paper. After marking for identification, the coupons were degreased and weighed. The "handle" of each coupon was painted with a rubberized plastic coating. Twelve cells were used in the course of this work, numbered from 1 to 12 . The 
conditions for each of them, as well as some of the results, are collected in Table I.

The conductivity in the medium was controlled by varying the concentration of $\mathrm{NaCl}$ in solution. Four concentrations of $\mathrm{NaCl}$ were used, $3.5 \%, 0.35 \%, 0.035 \%$ and $0.0035 \%$ by weight of $\mathrm{NaCl}$ in distilled water, while the mass transport conditions were varied by using a corrosive medium of either aqueous $\mathrm{NaCl}$ solutions or sand of various grain sizes saturated with the $\mathrm{NaCl}$ solutions. The sand medium was prepared by adding solution to high quality standard silica sand, ASTM designation C-109 and C-190, which had been further sieved and washed. The diameter of the sand was measured with an optical microscope, obtaining an average value and the standard deviation. The pore to volume ratio was determined from dry weight and volume measurements, where the specific gravity used for sand was $2.65 \mathrm{~g} / \mathrm{cm}^{3}$. Data characterizing the sand are reported in Table I I.

Table I

Properties of the Corrosive Media

\begin{tabular}{|c|c|c|c|c|}
\hline $\begin{array}{c}\text { Cell } \\
\text { No. }\end{array}$ & Medium & $\begin{array}{c}\text { NaCl conc. } \\
\%\end{array}$ & $\begin{array}{c}\text { Conductivity } \\
\text { S/cm }\end{array}$ & $\begin{array}{c}\text { Diffusion Coeff. } \\
\mathrm{cm}^{2} / \mathrm{s} \times 10^{7}\end{array}$ \\
\hline 1 & solution & 3.5 & $4.50 \times 10^{-2}$ & 109 \\
2 & solution & 0.35 & $5.85 \times 10^{-3}$ & 140 \\
3 & solution & 0.035 & $6.90 \times 10^{-4}$ & 154 \\
4 & solution & 0.0035 & $7.69 \times 10^{-5}$ & 154 \\
5 & sand 2/solution & 3.5 & $1.22 \times 10^{-2}$ & 25.8 \\
6 & sand 2/solution & 0.35 & $1.82 \times 10^{-3}$ & 3.3 \\
7 & sand 2/solution & 0.035 & $2.19 \times 10^{-4}$ & 11.3 \\
8 & sand 2/solution & 0.0035 & $4.10 \times 10^{-5}$ & 4.82 \\
9 & sand 1/solution & 0.0035 & $5.92 \times 10^{-5}$ & 4.09 \\
10 & sand 2/solution & 0.0035 & $4.17 \times 10^{-5}$ & 2.57 \\
11 & sand 3/solution & 0.0035 & $7.52 \times 10^{-5}$ & 6.14 \\
12 & sand 4/solution & 0.0035 & $9.35 \times 10^{-5}$ & 8.44 \\
\hline
\end{tabular}


Table II

Size Characterization of the Sand

\begin{tabular}{|c|c|c|c|c|}
\hline Hem & $\begin{array}{c}\text { Sieve } \\
\text { Number }\end{array}$ & $\begin{array}{c}\text { Aver. size } \\
\mathrm{mm}\end{array}$ & $\begin{array}{c}\text { Stand. dev. } \\
\mathrm{mm}\end{array}$ & $\begin{array}{c}\text { pore/volume } \\
\text { ratio }\end{array}$ \\
\hline sand 1 & $30-40$ & 0.56 & 0.063 & 0.39 \\
sand 2 & $40-50$ & 0.48 & 0.066 & 0.40 \\
sand 3 & $50-60$ & 0.35 & 0.035 & 0.40 \\
sand 4 & $60-100$ & 0.27 & 0.052 & 0.41 \\
\hline
\end{tabular}

\section{MEASUREMENT OF THE TRANSPORT CONDITIONS}

Electrical conductivity was measured between the cylindrical gold electrode and the circumferential stainless steel electrode, using the high frequency limit of the a.c. impedance spectra. Calibration was carried out using NIST Standard Reference solutions having resistivities of $10000 \Omega \cdot \mathrm{cm}$, $2000 \Omega \cdot \mathrm{cm}$, and $1000 \Omega \cdot \mathrm{cm}$. The values, in Siemens $/ \mathrm{cm}$, calculated for both aqueous solution and sand as a function of the $\mathrm{NaCl}$ concentration are shown in Fig. 2. The data in solution are in excellent agreement with the values reported in the literature [8].

In the presence of sand the conductivity measured depended not only on the $\mathrm{NaCl}$ concentration, but also on the transport hindrance created by the presence of sand. Lack of reproducibility in the packing of the sand accounted for the scatter in the conductivity values. For instance in the 5 cells ( 8 to 12) where the $\mathrm{NaCl}$ concentration was the same, the conductivity varied by a factor of 2 , but there was no obvious correlation with sand grain size.

Since the availability of oxygen is one of the main factors affecting the corrosion characteristics, the mass transport properties of the corrosive media used in this work were measured by deriving the diffusion coefficient of oxygen in a chronoamperometric experiment. The gold electrode was cathodically polarized to $-600 \mathrm{mV}$ versus a saturated calomel electrode (SCE), and the reduction current measured over a period of time. The rate of oxygen reduction at the gold surface is related to the concentration and the diffusion coefficient of oxygen through the medium. 
From Fick's first law, the current carried by a diffusing reactive species on an electrode of total surface $S$ is given by

$$
I(t)=z F D \int_{S} \frac{\partial C(0, t)}{\partial \vec{n}} d S
$$

where $\frac{\partial C(0, t)}{\partial \vec{n}}$ is the concentration gradient perpendicular to the electrode surface, and the integration is carried out over the whole surface. $C(0, t)$ is the concentration at the interface, and during the chronoamperometric transient is assumed to be zero.

In the case of a cylindrical electrode, the current I can be expressed in the form [9]

$$
I(t)=2 \pi \operatorname{LzFDC}_{0}\left[\frac{1}{\sqrt{\pi \varphi}}+\frac{1}{2}-\frac{1}{4} \sqrt{\frac{\varphi}{\pi}}+\frac{1}{8} \varphi+\ldots . .\right]
$$

where $\varphi=D t / r^{2}, z$ is the number of redox equivalents per mole of reactant, $F$ is the Faraday constant, $L$ the length and $r$ the radius of the cylindrical electrode, $C_{0}$ the initial concentration of the electroactive species, $D$ its diffusion coefficient and the time $t$ is measured from the beginning of the transient. Equation (2) is a good approximation as long as $\varphi$ does not exceed 0.1 . It should be noted that the first term in (2) is the same as Cottrell's equation for planar geometry, while the second term is independent of time.

Introducing in (2) the values appropriate (Table III) for oxygen reduction, according to the reaction

$$
\mathrm{O}_{2}+4 \mathrm{e}^{-}+2 \mathrm{H}_{2} \mathrm{O}=4 \mathrm{OH}^{-}
$$

in an air-saturated solution [10], and for the cell geometry of Fig. 1, that is 
Table III

Constants Used in Calculating Transient Current

\begin{tabular}{|c|c|c|c|c|}
\hline$z$ & $L \mathrm{~cm}$ & $\mathrm{C}_{0}, \mathrm{~mol}_{\mathrm{cm}}^{3}$ & $\mathrm{D}, \mathrm{cm}^{2} / \mathrm{s}$ & $\mathrm{r}, \mathrm{cm}$ \\
\hline 4 & 2 & $2 \times 10^{-7}$ & $1.5 \times 10^{-5}$ & 0.025 \\
\hline
\end{tabular}

plotting the total current as well as the first term only versus the reciprocal of the square root of time, as shown in Fig. 3, at least within the limits of validity of (2), the cylindrical electrode behaves in a way very similar to a planar electrode, the only significant difference being a constant offset corresponding to the second term, which does not affect the slope. From the value of the slope and of the offset it is possible to obtain both the diffusion coefficient $D$ and the concentration $\mathrm{C}_{0}$.

The experimental results are shown in Fig. 4, 5 and 6 . In the case of the measurements done in aqueous solution (Fig. 4), $C_{0}$ and $D$ have been calculated from a linear least squares fit of the experimental points. However, for the most dilute solution (cell 4), the experimental points do not follow a straight line. In this cell, where the solution resistance, as measured by electrode impedance spectroscopy (EIS), is of the order of $2000 \Omega \cdot \mathrm{cm}^{2}$, the ohmic drop, which at the beginning of the transient can exceed $200 \mathrm{mV}$, bringing the potential below the value necessary to achieve current limiting conditions at the electrode. This high resistance, however, was not a problem for the measurements in sand, since the current was at least one order of magnitude smaller, and the ohmic drop was negligible. The calculated values are given in Table IV.

Table IV

Diffusion Coefficent and Oxygen Concentration Values Calculated from Experimental Data Obtained in Aqueous Solutions

\begin{tabular}{|c|c|c|c|c|}
\hline NaCl conc. \% & Intercept $\times 10^{2}$ & Slope & $\mathrm{D} \times 10^{5}$ & $\mathrm{C}_{0} \times 10^{4}$ \\
\hline 3.5 & 2.0172 & 0.1435 & 1.573 & 1.662 \\
0.35 & 2.0032 & 0.1629 & 1.210 & 2.158 \\
0.035 & 2.6747 & 0.1711 & 1.944 & 1.782 \\
\hline
\end{tabular}


In the chronoamperometric experiments in sand, however, because of the smaller values of the current and the larger scatter due to noise, the intercepts are often negative, so that simultaneous calculation of $D$ and $C_{0}$ is not possible. Interestingly, the intercept for cells 8 and 10 , where both $\mathrm{NaCl}$ concentration and sand size are the same, is positive, so that the calculation can be performed, and an idea of the reproducibility can be gleaned. The numerical values are given in Table $\mathrm{V}$.

\section{Table V}

Diffusion Coefficent and Oxygen Concentration Values Calculated from Experimental Data Obtained in Aqueous Solutions With Sand

\begin{tabular}{|c|c|c|c|c|}
\hline Cell No. & Intercept $\times 10^{4}$ & Slope $\times 10^{2}$ & $\mathrm{D} \times 10^{6}$ & $\mathrm{C}_{0} \times 10^{4}$ \\
\hline 8 & 10.043 & 1.511 & 3.516 & 0.370 \\
10 & 7.847 & 1.103 & 4.028 & 0.252 \\
\hline
\end{tabular}

It is interesting to note that the oxygen concentration is calculated to be between one third and a quarter of its value in dilute aqueous solutions. If the concentration calculated reflected the effect of the sand, since the porosity (defined as the ratio of the solution volume to the total volume) is close to 0.4 , the concentration would decrease in the same ratio, if the sand did not block completely part of the electrode surface, and by less than 0.4 if some decrease in effective surface area took place. Given these uncertainties, and the fact that the slopes in Fig. 5 and 6 do not follow any recognizable trend with $\mathrm{NaCl}$ concentration or sand grain size, it was decided that the slopes in all transients, whether caused by the packing of the sand or oxygen availability, were a fair index of the mass transport properties of the individual cells. A number, which can be considered an effective diffusion coefficient, was calculated from each slope, under the assumption that the oxygen concentration was $2 \times 10^{-4} \mathrm{M}$ in solution (cells 1 to 3 ) and $1 \times 10^{-4} M$ in sand (cells 5 to 12). This is the number reported in Table I. In the case of cell 4 , as explained above, no value could be calculated and $D$ is assumed to be the same as that calculated for cell 3 .

A further indication that differences in the packing of the sand are responsible for most of the scatter can be obtained by plotting the diffusion coefficient versus the conductivity for cells 8 to 12, for which the $\mathrm{NaCl}$ 
concentration is the same, as shown in Fig. 7. The two quantities are linearly correlated reasonably well, pointing to a common factor affecting the results. Examination of all the $\mathrm{D}$ values obtained in sand suggests that oxygen diffusion is independent of electrical conductivity, with an effective diffusion coefficient of about $6 \times 10^{-7} \mathrm{~cm}^{2} / \mathrm{s}$, about 20 times less than in water, but a significant scatter (standard deviation $=3 \times 10^{-7}$ ), due to local packing of the sand.

\section{CORROSION RATE MEASUREMENTS}

The corrosion of the steel specimens was monitored every two weeks for a period of about 3 months by measuring the corrosion potential and by taking an impedance spectrum at that potential. The electrode admittance per unit surface area $Y$, which is proportional to the corrosion rate $I$ (in current density units) according to the formula [11]

$$
I=K Y
$$

was then calculated from the impedance data by subtracting the impedance limit at high frequency, that is the electrolyte resistance, from the zero-frequency limit of the real impedance. Gravimetric weight loss measurements on the specimens were also made at the end of the exposure period, for verification of the electrochemical measurements.

The EIS measurements were made using a computer controlled potentiostat and a frequency response analyzer. Small sinusoidal potential perturbations were applied (about $10 \mathrm{mV}$ peak-to-peak) to the WE, reducing the possibility that the measurement would disturb the condition of the specimen. Frequency scans were taken from $10 \mathrm{mHz}$ to $1 \mathrm{kHz}$, and 3 points per decade were obtained. Examples of the of the type of data obtained for steel coupons in solutions of four different conductivities are shown in Fig. 8 and 9. 
Table VI

Average Admitance and Averate Corrosion Rate

Values for the Cells

\begin{tabular}{|c||c|c|}
\hline Cell No. & $\begin{array}{c}\text { Admittance } \\
\mu \mathrm{S} / \mathrm{cm}^{2}\end{array}$ & $\begin{array}{c}\text { Corrosion Rate } \\
\mu \mathrm{A} / \mathrm{cm}^{2}\end{array}$ \\
\hline 1 & 474.8 & 7.52 \\
2 & 417.5 & 10.09 \\
3 & 282.5 & 9.87 \\
4 & 87.6 & 8.27 \\
5 & 83.6 & 1.02 \\
6 & 47.4 & 0.75 \\
7 & 32.7 & 0.46 \\
8 & 24.5 & 0.59 \\
9 & 25.2 & 0.44 \\
10 & 23.4 & 0.43 \\
11 & 25.8 & 0.38 \\
12 & 29.7 & 0.52 \\
\hline
\end{tabular}

The electrode admittance and corrosion potential readings for all cells are shown in Fig. 10, 11 and 12. Although there is scatter in these data, no trends with time could be reliably detected. For this reason, an average electrode admittance for each cell was calculated by summing all experimental values and dividing by the number of measurements. These are the values given in Column 2 of Table VI, while in column 3 the average corrosion rate, derived from the weight loss measurements, is reported.

The estimate of the value of the proportionality constant $K$ of formula (4) was obtained by plotting weight loss data versus the EIS data, as shown in Fig. 13. The best estimate of $\mathrm{K}$, indicated by the line on the plot, is $19 \mathrm{mV}$, with a standard deviation of 6 . This value appears to be reasonable, being not far from the value obtained by other workers for steel $[11,12]$.

\section{BIBUTION OF CORROSION OVER THE SURFACE}

Although the only form of corrosion occurring in these experiments is generalized corrosion, sometimes referred to as "uniform", it is well known that 
in practice the lack of uniformity is considerable $[13,14]$. If estimating the time necessary to perforate a plate of a given thickness is important, a way to quantify the lack of uniformity in corrosion, its evolution with time and its dependence on environmental conditions becomes critical. At the moment there are no guidelines for measuring lack of uniformity in corrosion. In this work we have devised a way to quantify it by analyzing the data provided by a profilometer. The instrument records the vertical displacements of a stylus drawn on a straight line. The length $L$ of the line employed in this work was 1.5 $\mathrm{cm}$, while the vertical sensitivity was $0.1 \mu \mathrm{m}$. One trace was recorded for each side of the specimens, after 78 days of exposure to the corroding medium, and after chemical cleaning in Clark's solution [15] to remove the corrosion scale. Typical traces recorded are shown in Fig. 14.

The instrument, after filtering out surface waviness of wavelength greater than $2.5 \mathrm{~mm}$, performs some statistical analysis of the data; in particular, it divides the length $L$ in 5 equal sections, and for each of them determines the vertical distance $Z_{i}$ between the highest and the lowest point. These values are averaged, producing an averaged roughness

$$
R=\frac{1}{5} \sum_{i=1}^{i=5} Z_{i}
$$

It also calculates a scatter

$$
S=\frac{1}{2} \sqrt{\sum_{i=1}^{i=5}\left(Z_{i}-R\right)^{2}}
$$

which is an indicator of the lack of uniformity in the roughness measurement at a wavelength of the order of $L / 10$. The results of the measurements in the eight different environments (four $\mathrm{NaCl}$ concentrations, in aqueous or sand medium) have been grouped together and averaged. The results are collected in Table V I I.

\section{DISCUSSION}

The results of this work indicate that the corrosion rate depends strongly on the ease with which oxygen is transported in the electrolyte. In spite of the uncertainties which are present in the evaluation of the effective diffusion 
coefficient $D$, as discussed in the preceding section, Fig. 15 shows unequivocally the dependence of the corrosion rate on $D$. The least squares line has a slope of 0.8 , which given the scatter of the data, is not significantly different from 1, showing a linear dependence of the rate on oxygen transport.

The dependence of the corrosion rate on solution conductivity, or more precisely on electric charge transport, as summarized in Fig. 16, on the contrary, is very weak. Considering the uncertainties in the values, it can be concluded, as a first approximation, that charge transport is not important in determining the overall corrosion rate.

A question left open is which process is rate-determining in these corrosion tests. In order to provide some clue on this issue, all corrosion rate values as calculated from admittance data and transformed into current densities by multiplying them by the constant $\mathrm{K}$, as discussed above, were plotted against the corrosion potential as measured at the time of the EIS measurements. This kind of a current/potential plot is shown in Fig. 17. In spite of the scatter, it seems fairly clear that, as summarized by the two separate least square fits, one for the data in solution and the other for the data in sand, in the first case the slope is negative, while in the second it is positive. An explanation for this is that in solution the corrosion rate is not under oxygen diffusion control, so that higher corrosion rates occur when the anodic reaction is easier, decreasing the corrosion potential. The opposite occurs in sand, and higher corrosion rates are observed when oxygen transport is easier, with a corresponding increase in corrosion potential.

As far as the roughness data are concerned, comparison with the results obtained on specimens before the corrosion tests (typically, $R=3, S=0.5$ ) shows that, in sand, the exposure times were too short to significantly affect the surface finish. However, the data in the aqueous medium provide a way to estimate the influence of the solution conductivity on the lack of uniformity in the corrosion process. The values of $R$ are an indication of the development of small scale roughness, while $S / R$ can be thought of as a measure of the development of large scale disuniformities, perhaps localized attack akin to pitting. From the data shown in Table V I I, it is evident that roughness, both small and large scale, is much more pronounced when the solution conductivity is low. It should be remembered that all specimens were exposed to the corroding environment for the same time, and also that the corrosion rate itself 
did not vary much from cell to cell, in aqueous solution. Therefore, the values in Table V I I can be directly intercompared. A graphic representation of these results is given in Fig. 18.

Table V II

Characterization of the Surface Morphology of the Steel After Exposure in Aqueous and Sand Environments

\begin{tabular}{|c|c|c|c|c|c|}
\hline \multirow[t]{2}{*}{ Environment } & \multicolumn{2}{|c|}{ Roughness } & \multicolumn{2}{|c|}{ Scatter } & \multirow{2}{*}{$\begin{array}{l}\text { Ratio } \\
\text { SR }\end{array}$} \\
\hline & $R, \mu \mathrm{m}$ & St. dev. & $\mathrm{S}, \mu \mathrm{m}$ & St. dev. & \\
\hline Aq. $\quad 3.5 \% \mathrm{NaCl}$ & 9.3 & 2.9 & 4.2 & 2.1 & 0.45 \\
\hline $0.35 \%$ & 11.5 & 2.6 & 5.3 & 2.0 & 0.46 \\
\hline $0.035 \%$ & 20.1 & 7.2 & 14.8 & 9.0 & 0.74 \\
\hline $0.0035 \%$ & 54.8 & 7.6 & 39.7 & 4.2 & 0.72 \\
\hline Sand. $3.5 \% \mathrm{NaCl}$ & 3.65 & 0.38 & 0.8 & 0.5 & 0.21 \\
\hline $0.35 \%$ & 2.20 & 0.32 & 0.5 & 0.3 & 0.20 \\
\hline $0.035 \%$ & 4.30 & 0.63 & 0.7 & 0.3 & 0.17 \\
\hline $0.0035 \%$ & 3.42 & 0.75 & 0.9 & 0.4 & 0.27 \\
\hline
\end{tabular}

The lack of uniformity in the corrosion rate plays a more important role in determining the time for penetration of the container wall, than the average value of the corrosion rate. This is obvious in the case of pitting, but it is less appreciated when the type of corrosion is described as uniform. The data presented here on this point should be considered preliminary; because of insufficiently long exposure times, it was impossible to determine which role mass transport hindrance can play in inducing lack of uniformity. Also, no data were obtained as to the time evolution of the surface roughness. Both these points should be the subject of further work. 


\section{CONCLUSIONS}

The results indicate that the rate of oxygen transport and the resistivity of the environment influence the corrosion of steel in simulated soils, so that:

1) The rate of oxygen transport has a direct, almost linear, effect on the rate of corrosion over several orders of magnitude.

2) The rate of charge transport has very little effect on the rate of corrosion.

3) Corrosion becomes much more localized and less uniform as the conductivity of the environment decreases, at least in aqueous solutions. 


\section{REFERENCES}

[1] DOE, "Environmental Assessment - Yucca Mountain Site, Nevada Research and Development Area, Nevada", DOE/RW-0073, Volume 2, U.S. Dept of Energy, May 1986.

[2] DOE, "Environmental Assessment - Yucca Mountain Site, Nevada Research and Development Area, Nevada", DOE/RW-0073, Volume 1, U.S. Dept of Energy, May 1986.

[3] McCright, R.D., Weiss, H., "Corrosion Behavior of Carbon Steels Under Tuff Repository Environmental Conditions", UCRL-90875, October 1984.

[4] Oversby, V.M., McCright, R.D., "Laboratory Experiments Designed to Provide Limits on the Radionuclide Source Term For the NNWSI Project, Proceedings of Workshop on the Source Term for Radionuclide Migration From HLW or Spent Nuclear Fuel", UCRL-91257, November 1984.

[5] Westerman, R. E., Pitman, S. G., Haberman, J. H., "Corrosion Testing of Type 304L Stainless Steel in Tuff Groundwater Environments", UCRL 21005, SANL 616-007, NBS 129, December 1987.

[6] McCright, R. D., Weiss, H., Junas, M., Logan, R. W., "Selection of Candidate Canister Materials For High-Level Nuclear Waste Containment in a Tuff Repository", UCRL-89988, April 1984.

[7] Jansen, G., "Expected Waste Package Performance for Nuclear Waste Repositories in Three Salt Formations, BMI/ONWI-655, August 1987.

[8] Handbook of Chemistry and Physics, 54th Edition, p. D-222.CRC Press, Cleveland, $\mathrm{OH}$ (1973)

[9] .Adams, R. N., "Electrochemistry at Solid Electrodes", p. 61. M. Dekker, New York, (1969)

[10] Jovancicevic, V., Zelenay, P., Scharifker, B. R., Electrochim. Acta, 32, 1553 (1987)

[11] Mansfeld, F., "Advances in Corrosion Science and Technology", Vol. 6, p. 163, M. G. Fontana, R. W. Staehle, eds. Plenum Press, New York, (1976)

[12] Kasahara, K., Kajiyama, F., Corrosion, 39, 475 (1983)

[13] Romanoff, M. "Underground Corrosion". NBS Circular 579 (1957)

[14] Gerhold, W.F., Escalante, E., Sanderson, B.T., "The Corrosion Behavior of Selected Stainless Steels in Soil Environments", National Institute of Standards and Technology, NBSIR-81-2228, February 1981.

[15] ASTM-G 1-81. "Prepaning, Cleaning, and Evaluating Corrosion Test Specimens". Vol. 03.02. ASTM, Philadelphia, PA. 

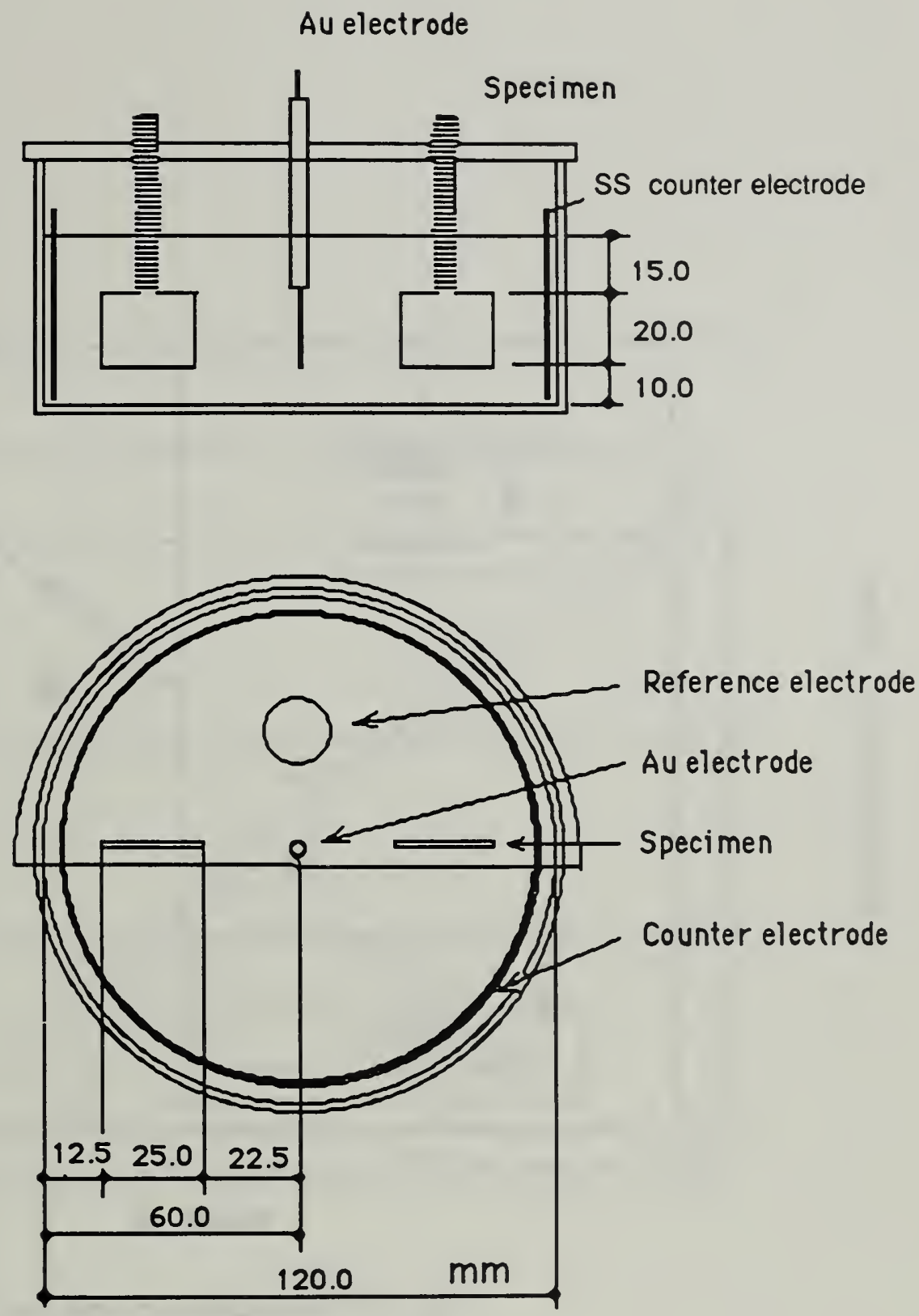

Figure 1. Schematic drawing of the Cell 


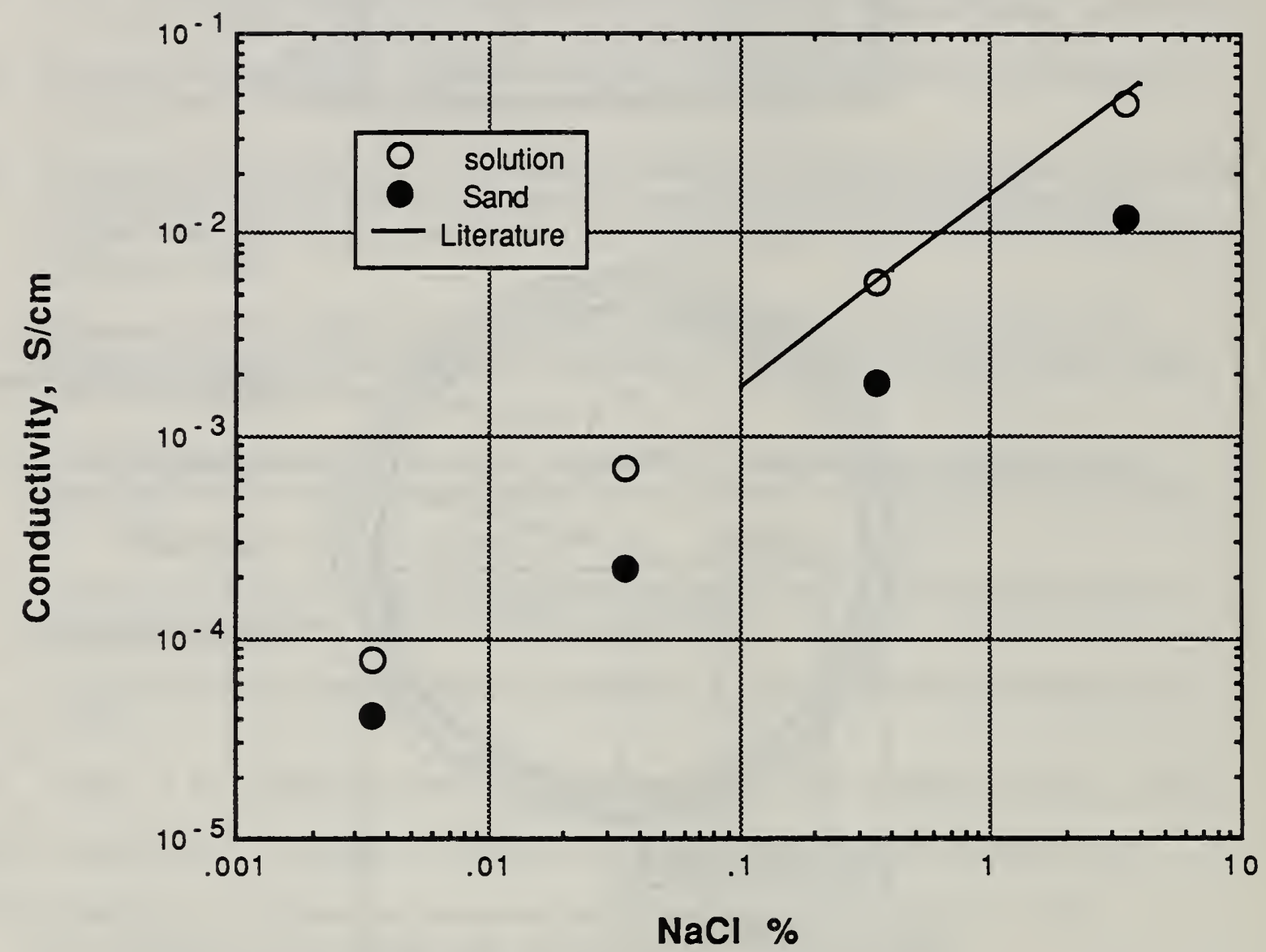

Fig. 2. Conductivity of various media 


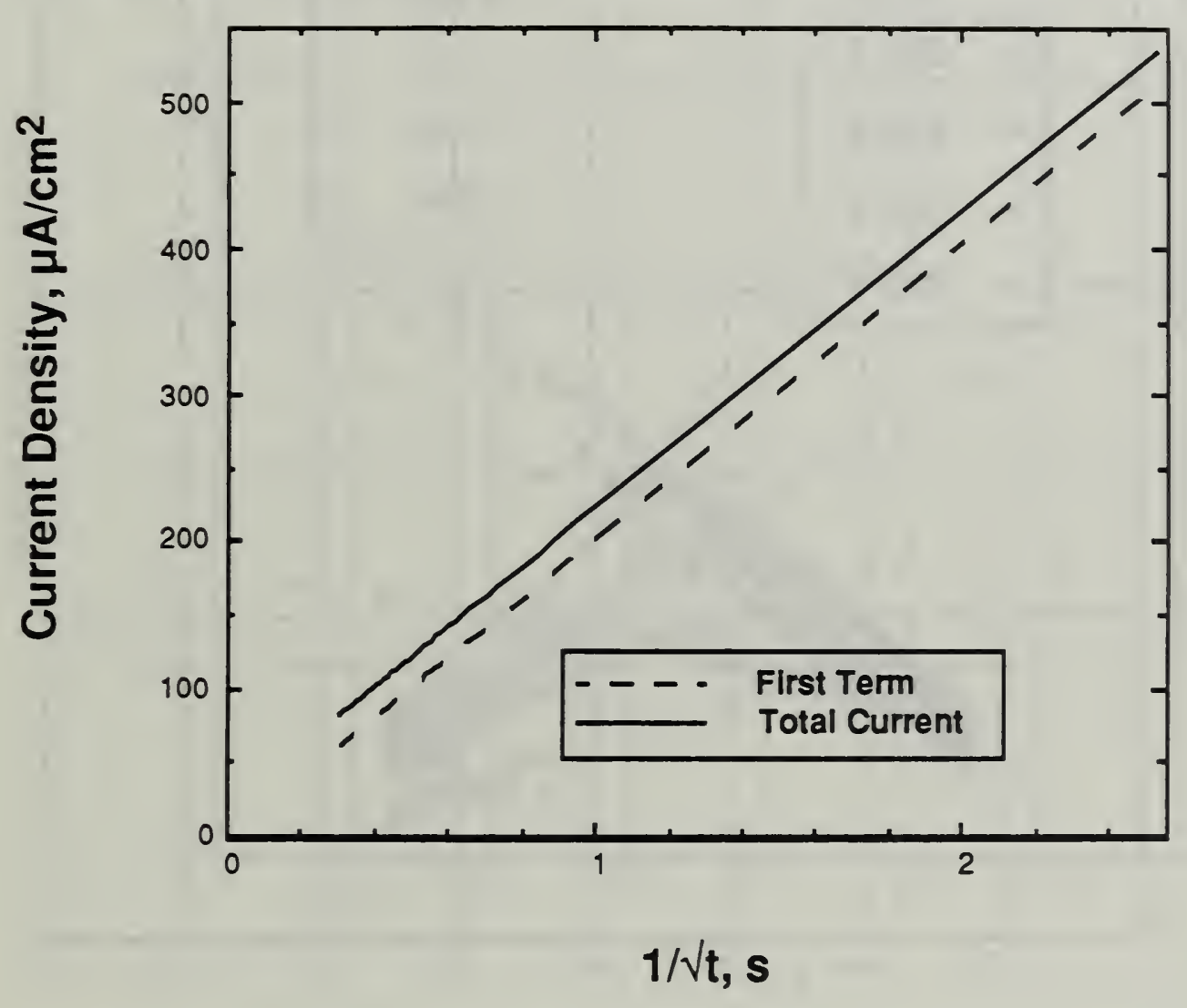

Fig. 3. Calculated current density for chronoamperometric transient on a cylindrical electrode 


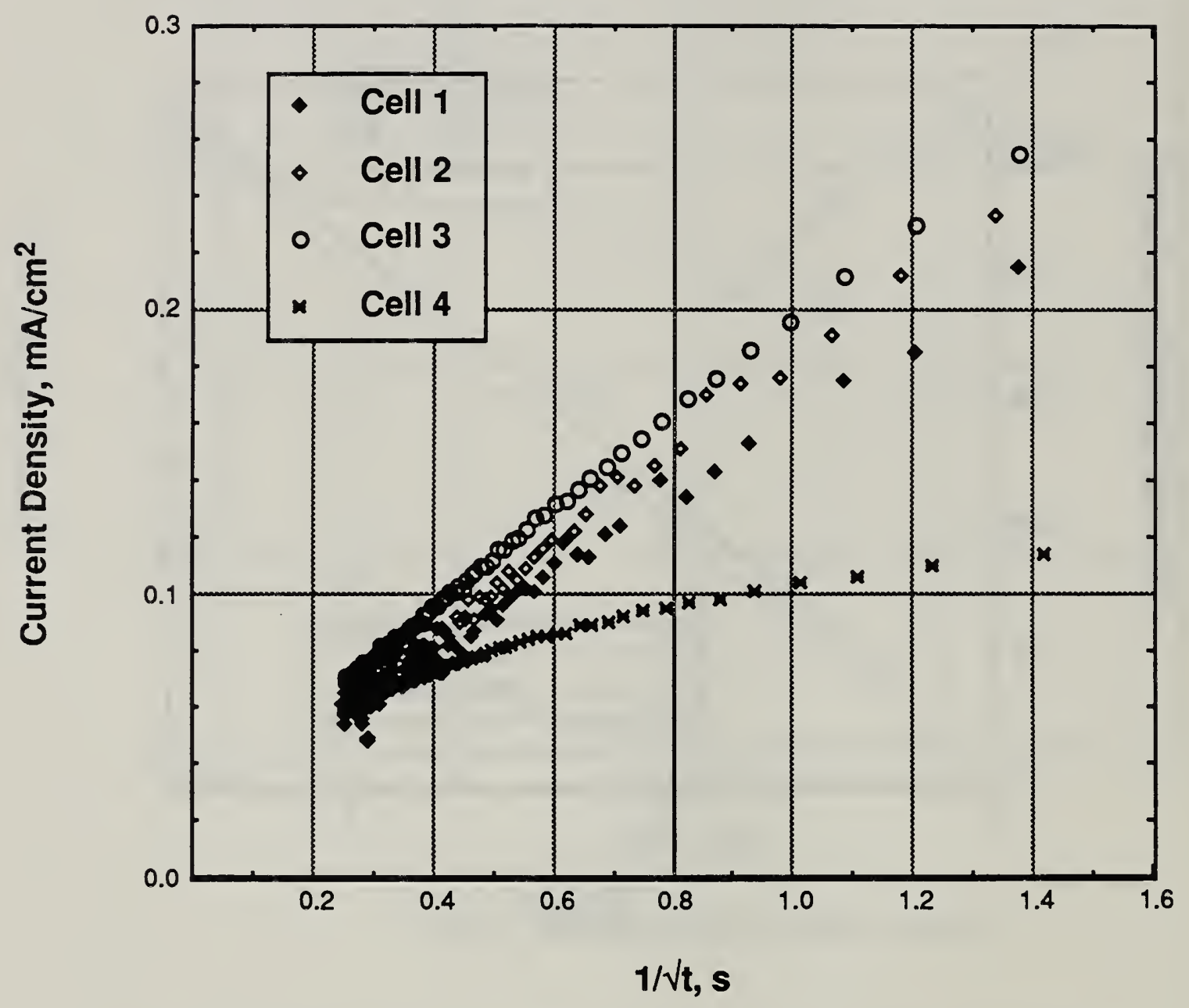

Fig. 4. Chronoamperometric transients. Cells 1, 2, 3 and 4. 


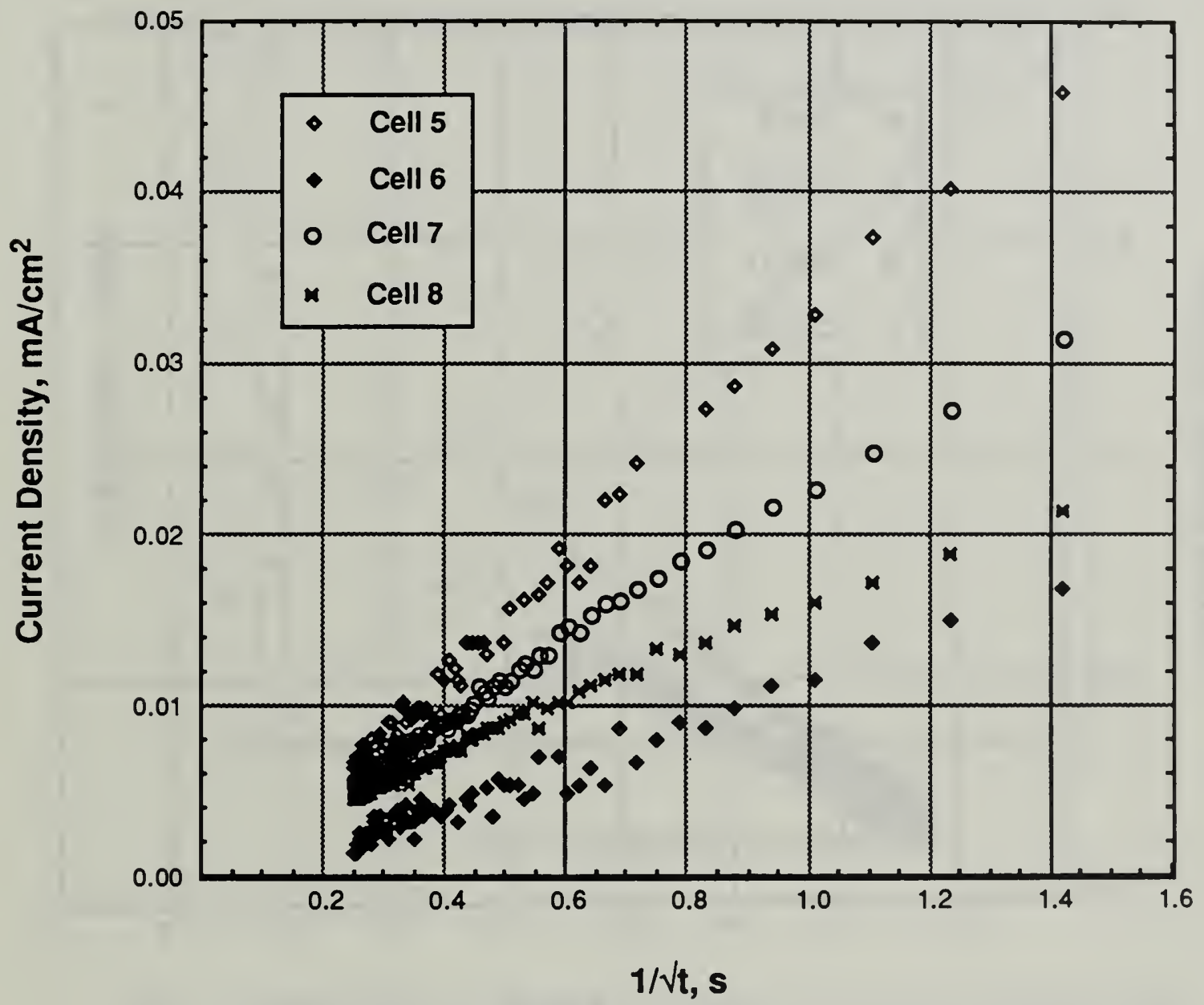

Fig. 5. Chronoamperometric transients. Cells 5, 6, 7 and 8. 


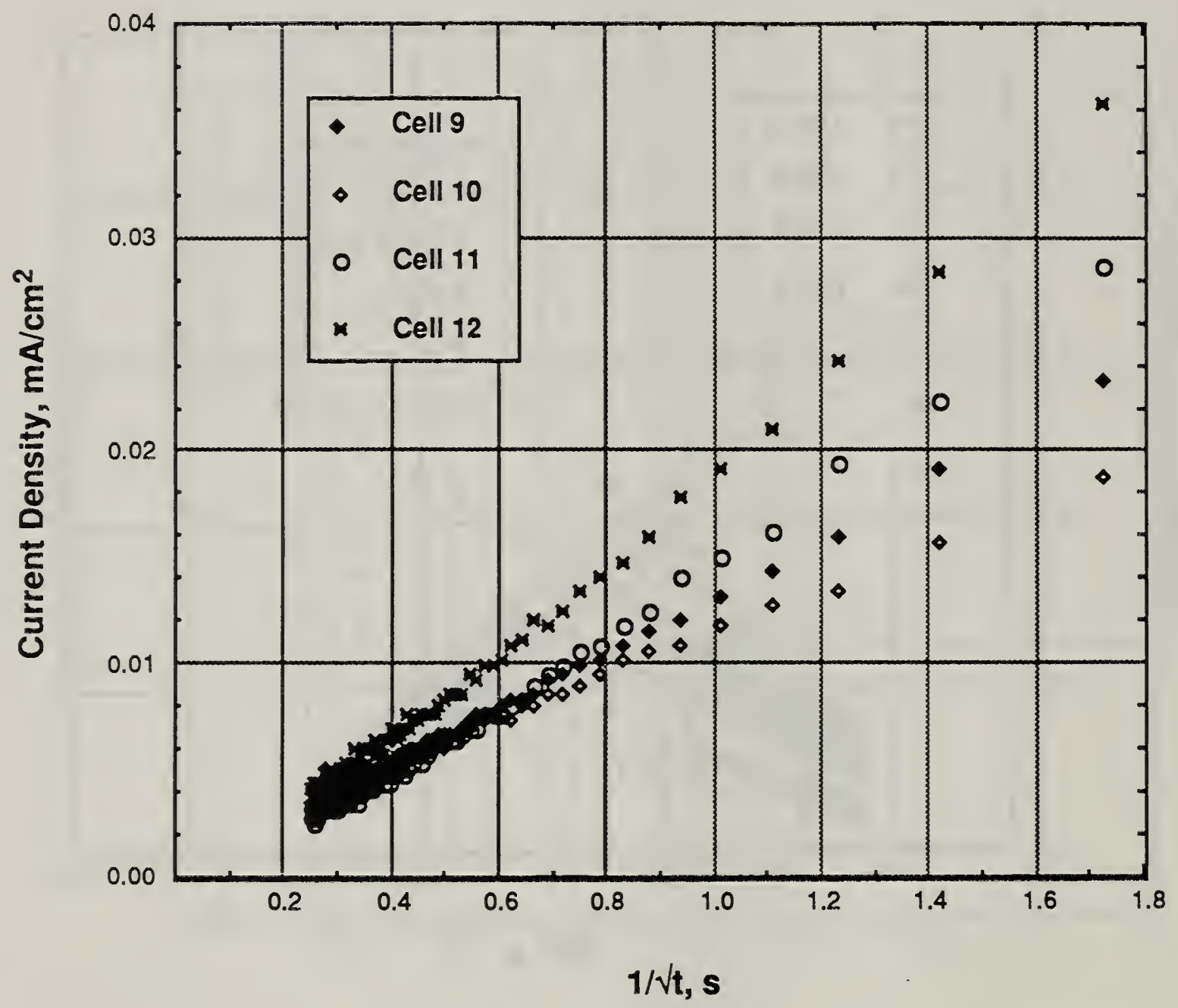

Fig. 6. Chronoamperometric transients. Cells 9, 10, 11 and 12. 


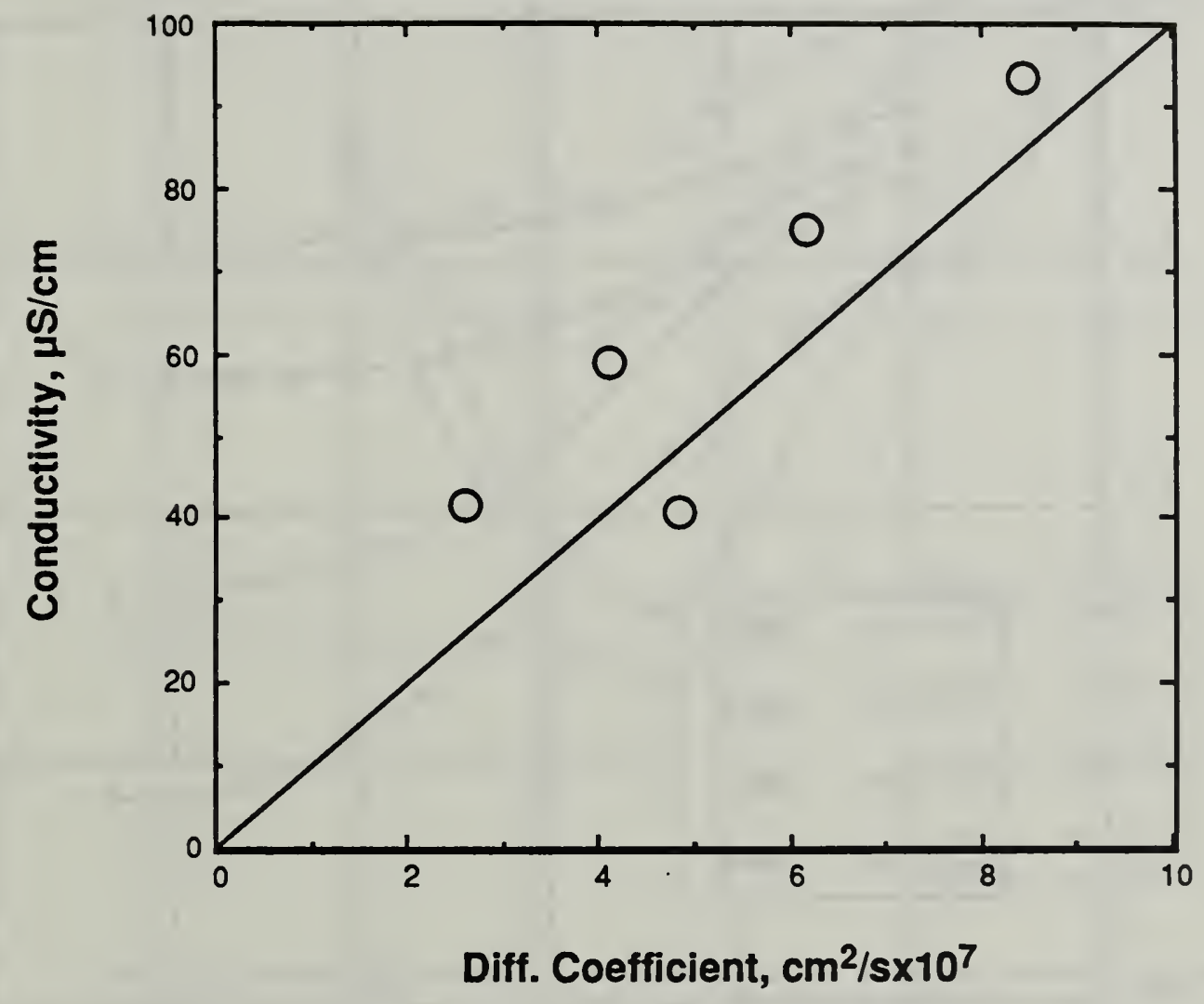

Fig. 7. Conductivity vs. diffusion coefficient in sand and $0.0035 \% \mathrm{NaCl}$ 


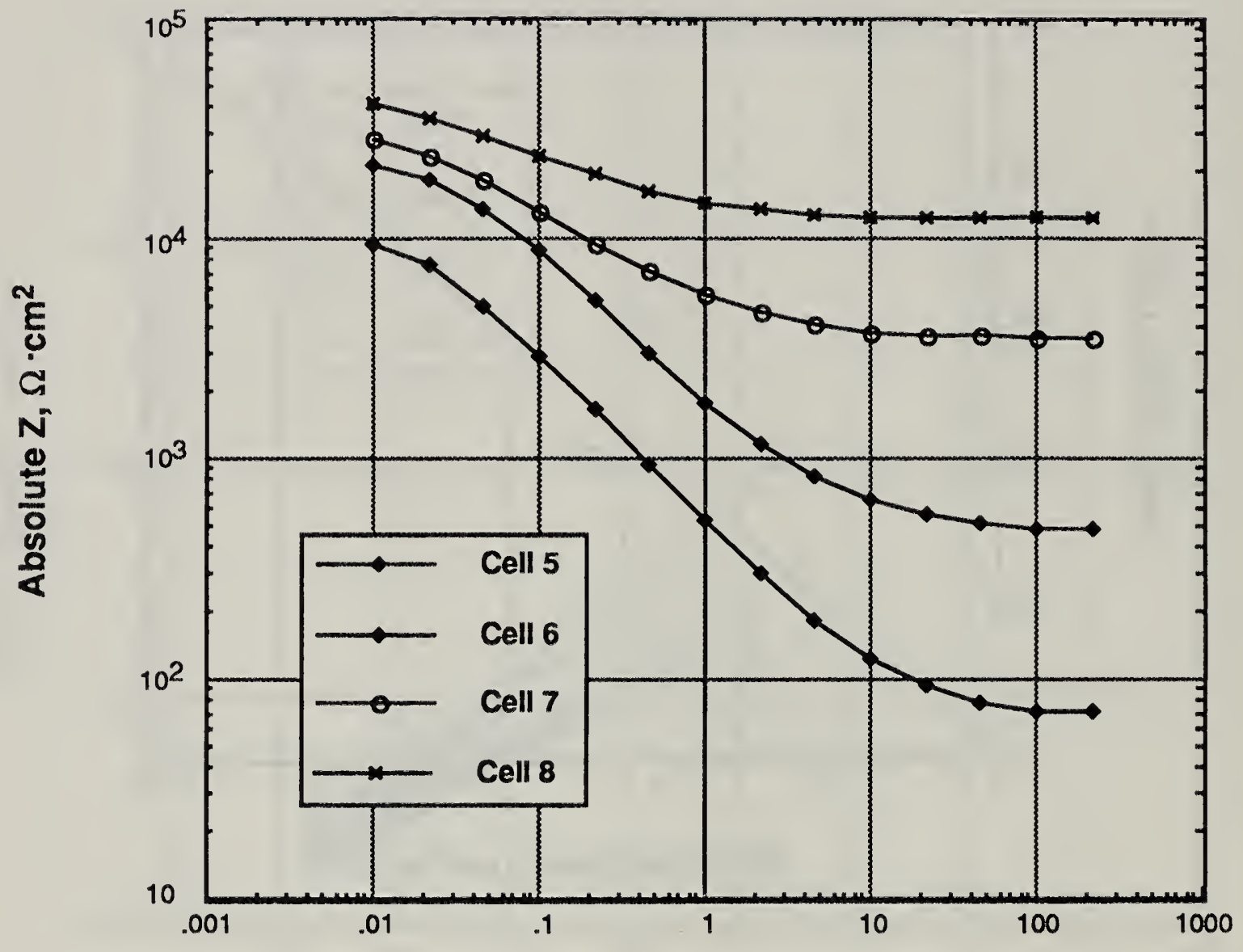

Frequency, $\mathrm{Hz}$

Fig. 8. Examples of EIS results. Absolute $Z$ vs. frequency 


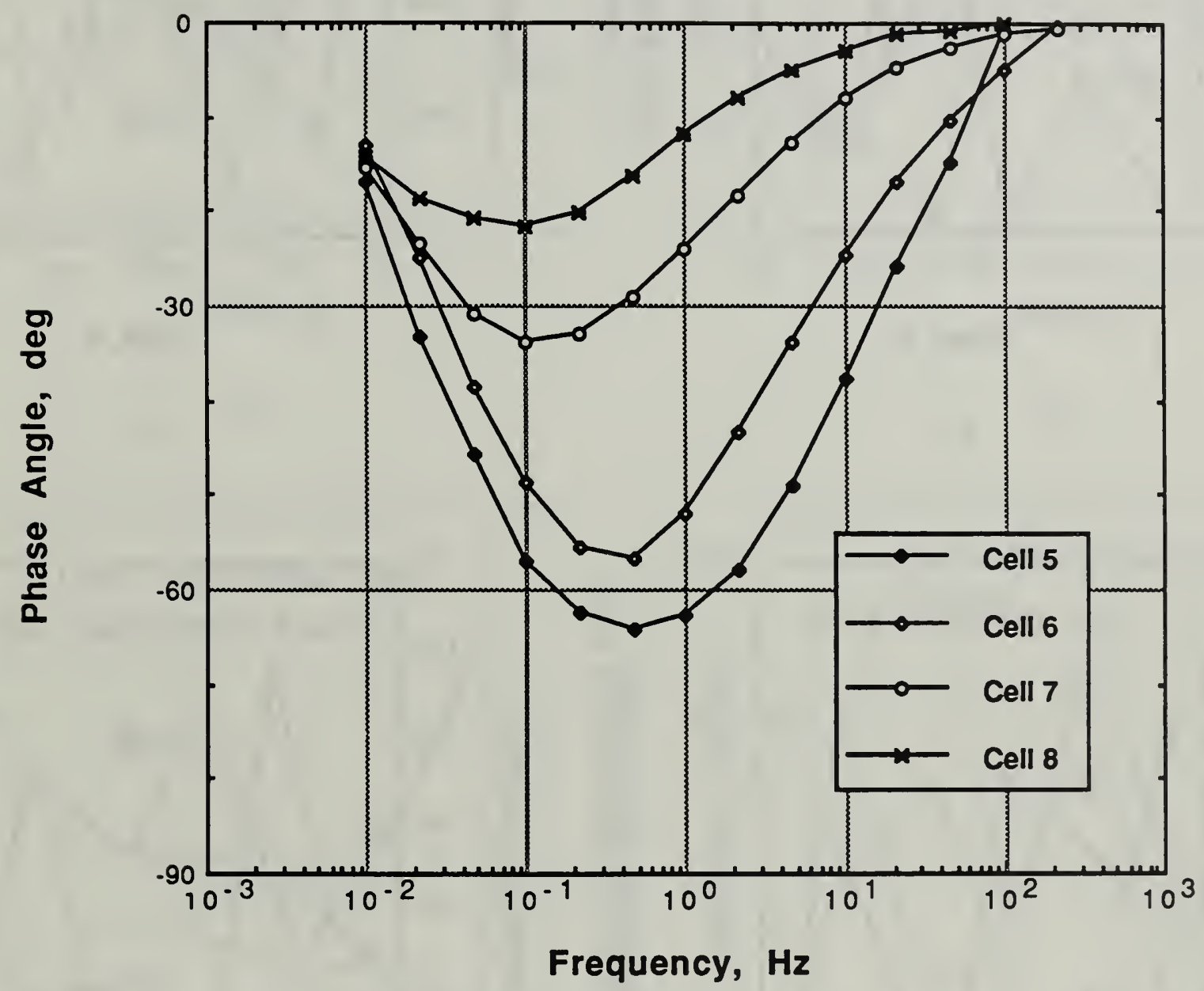

Fig. 9. Examples of EIS data. Phase angle vs .frequency 


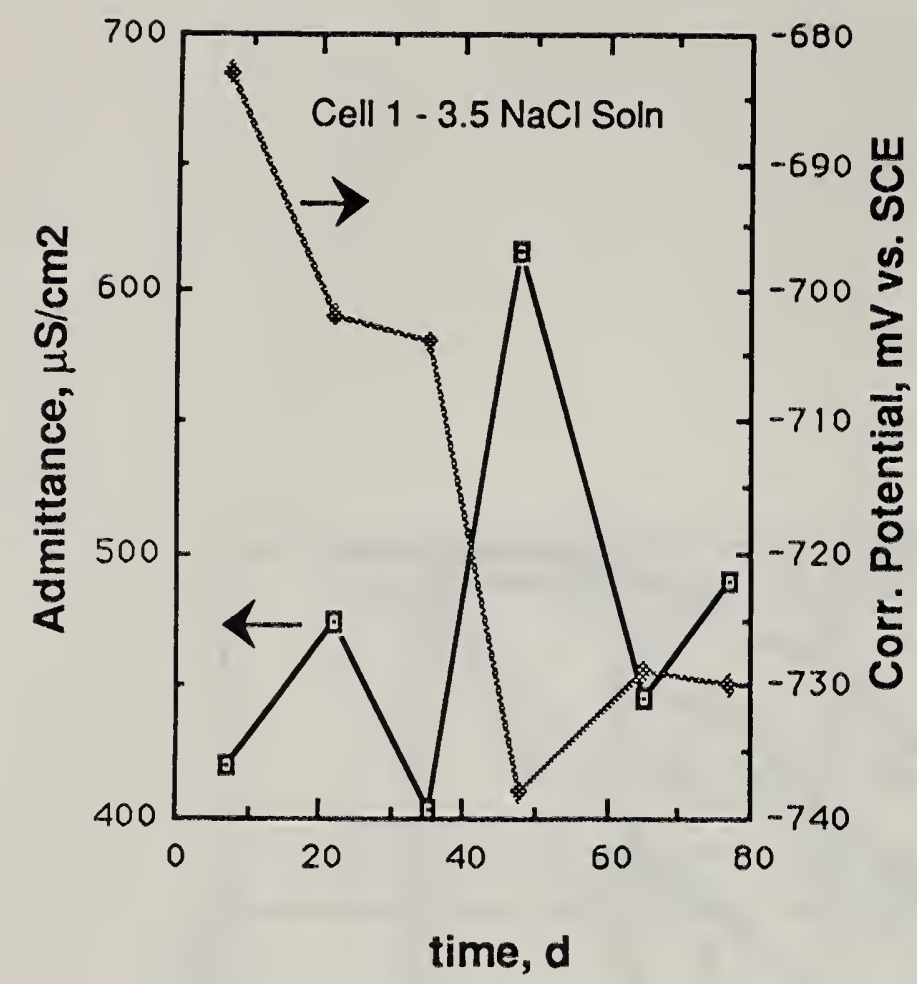

a)

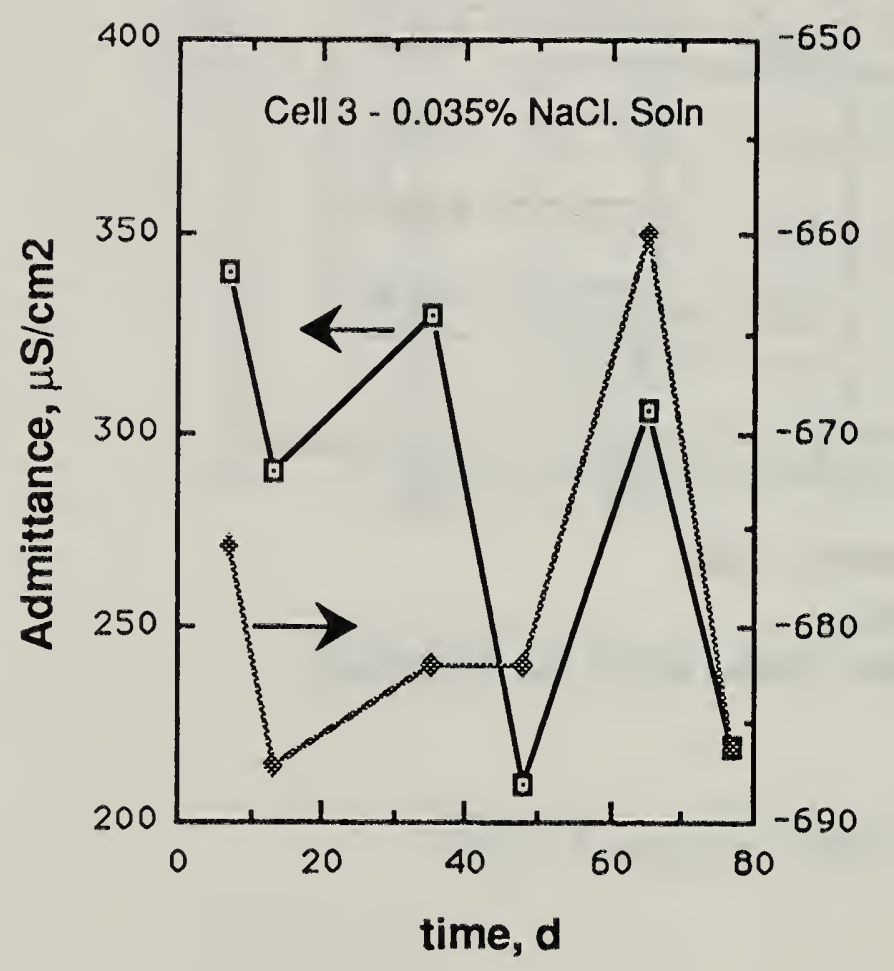

c)

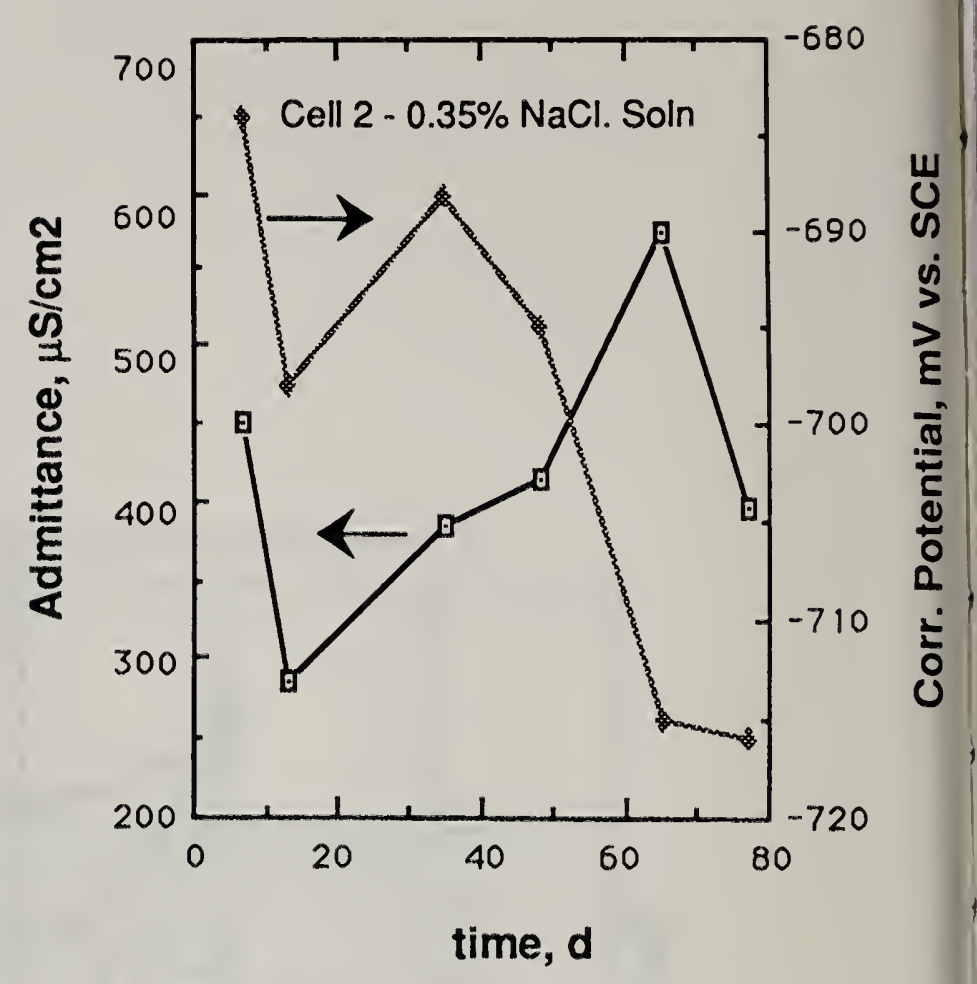

b)
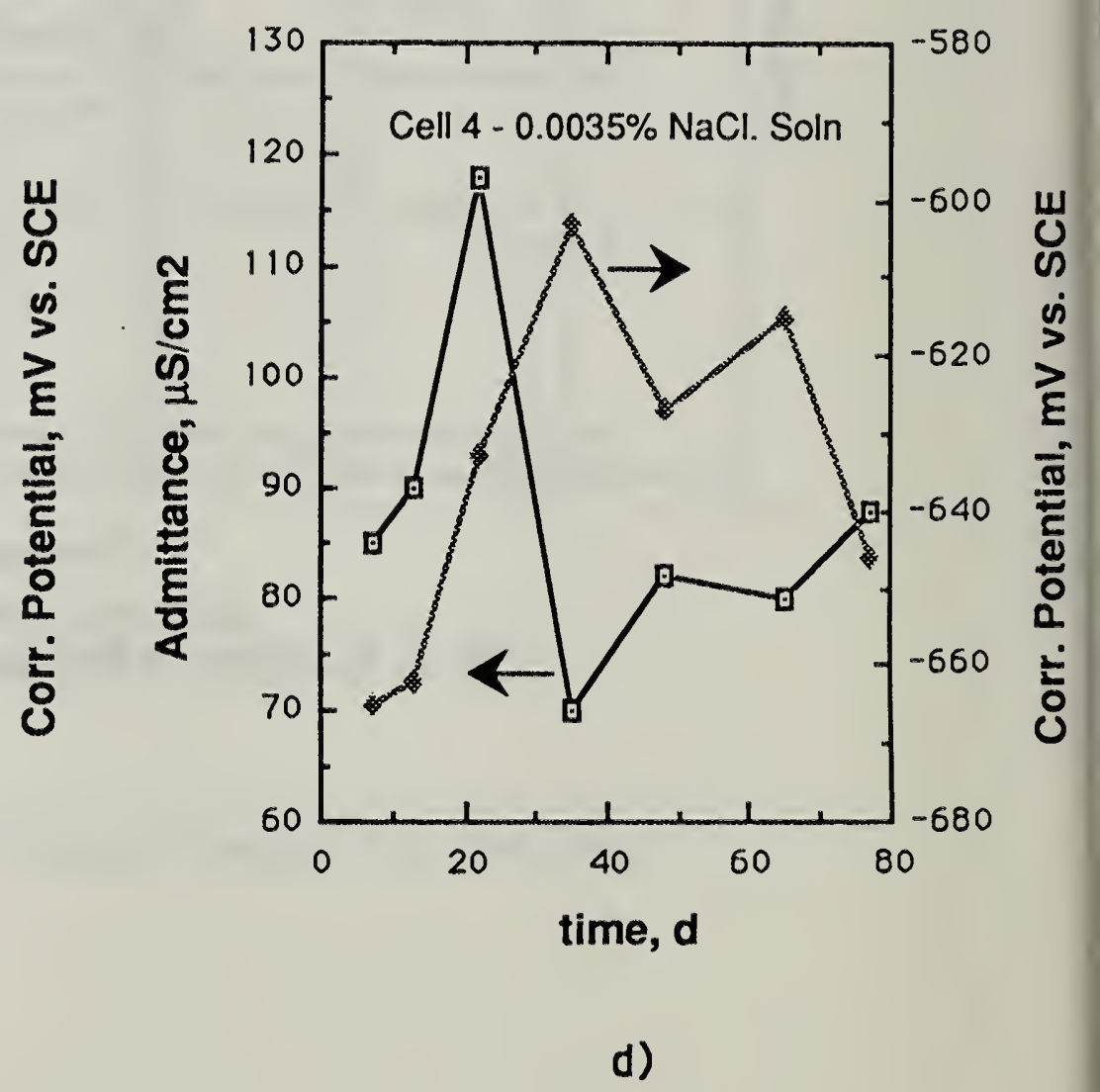

Fig. 10. Measured Electrode Admittance and Corrosion Potential. Cells $1,2,3$, and 4 


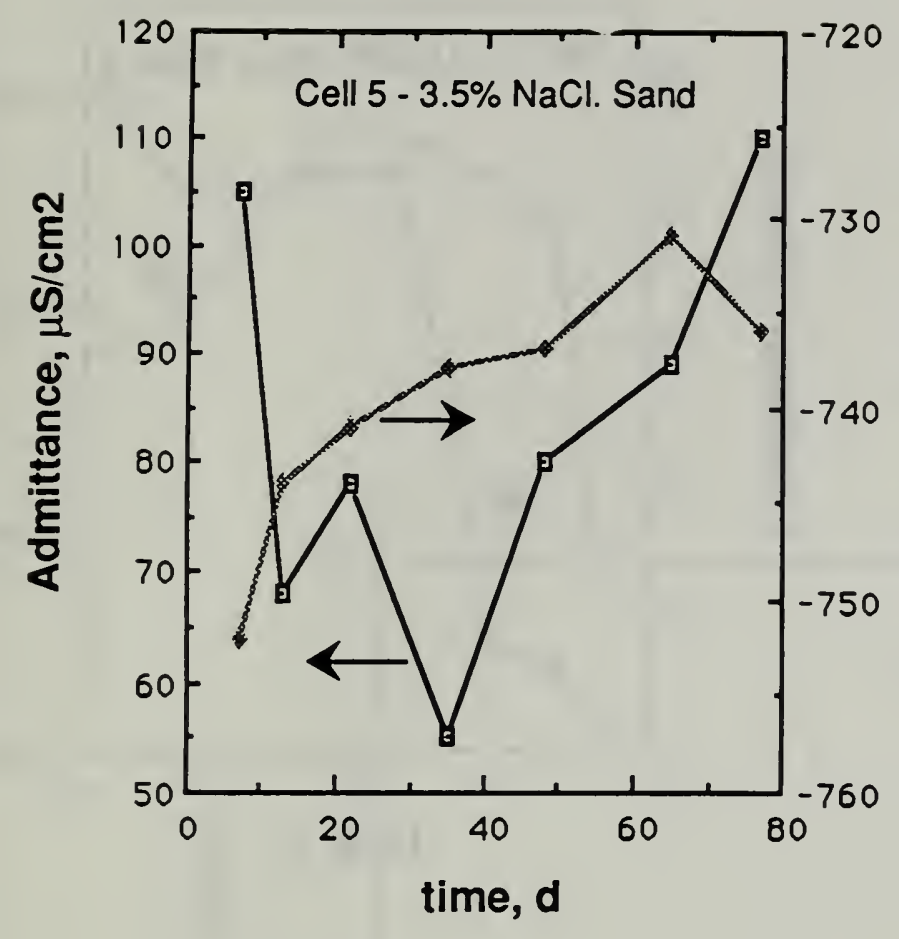

a)

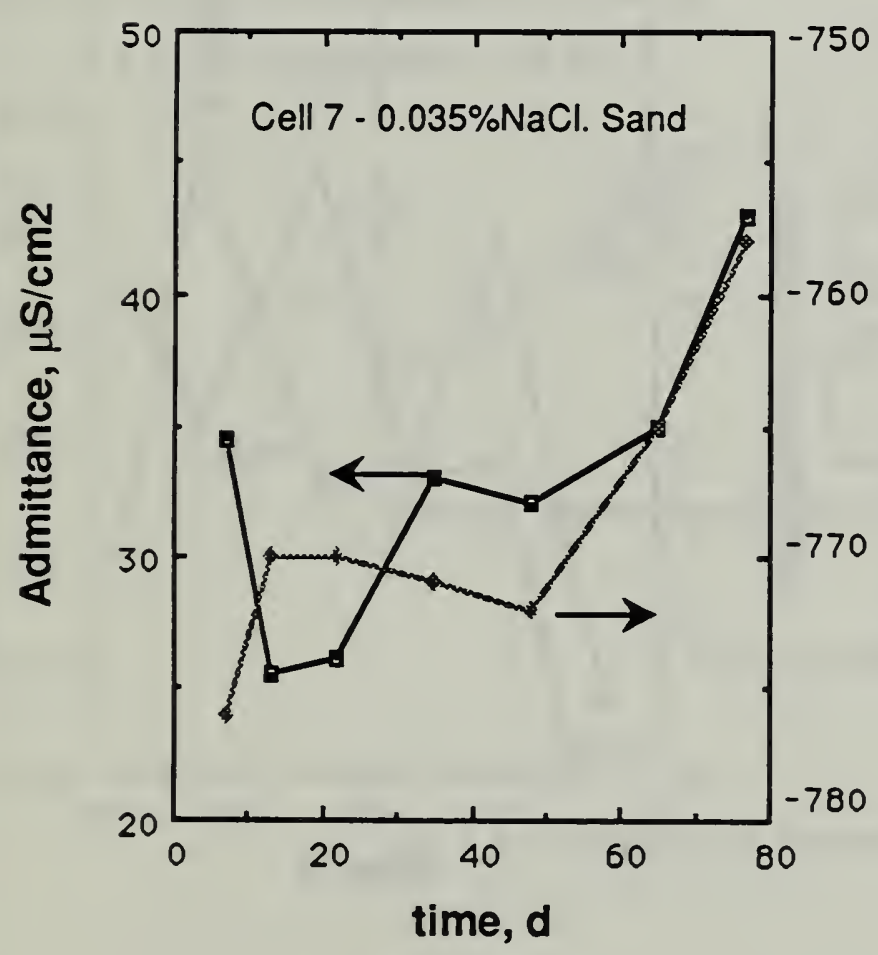

c)

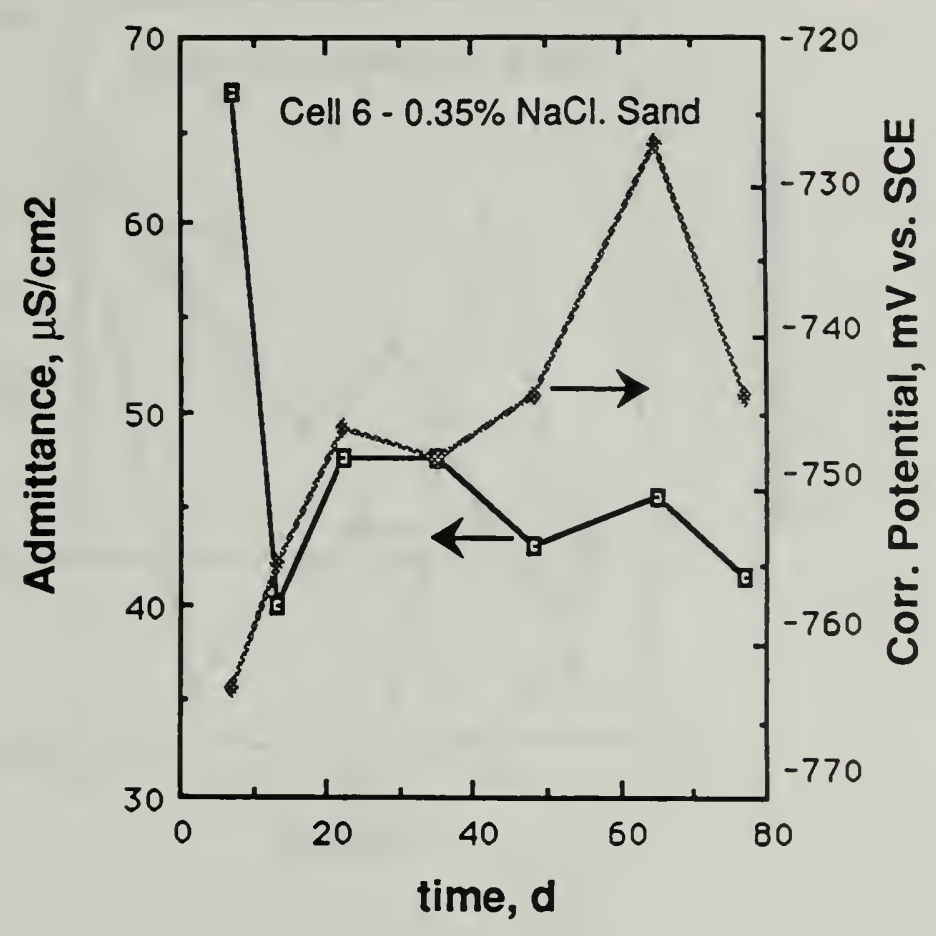

6)

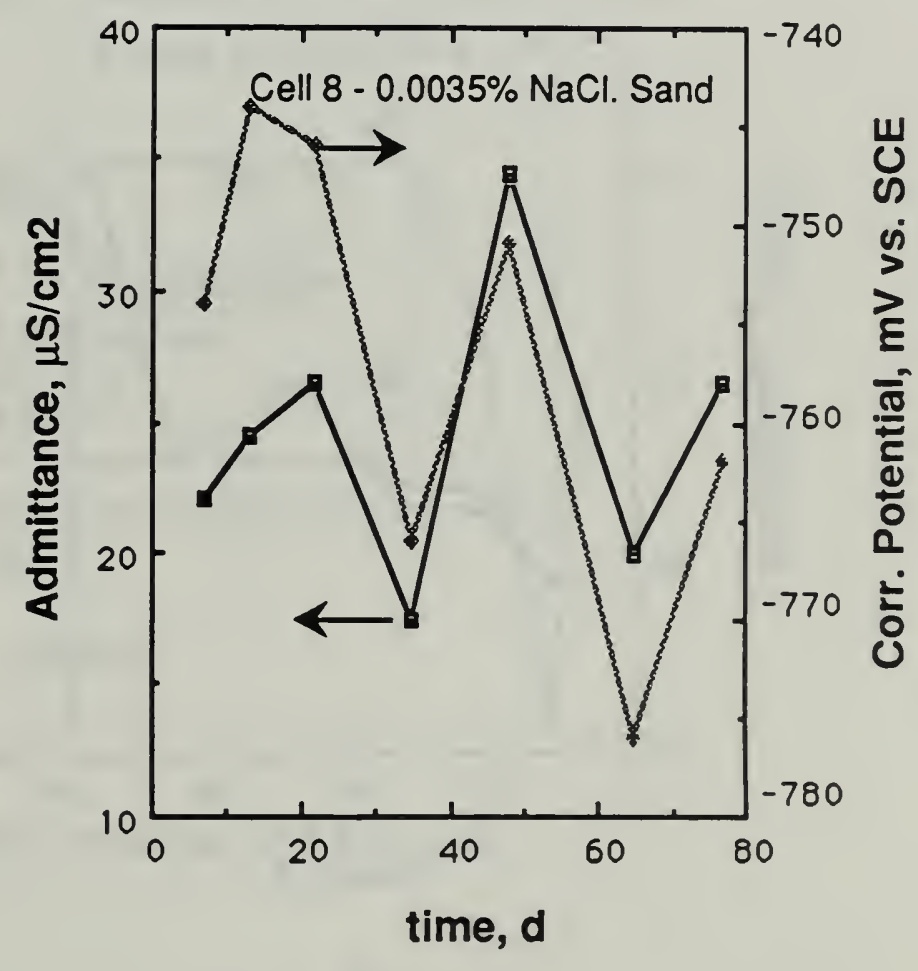

d)

Fig. 11. Measured Electrode Admittance and Corrosion Potential. Cells $5,6,7$, and 8 


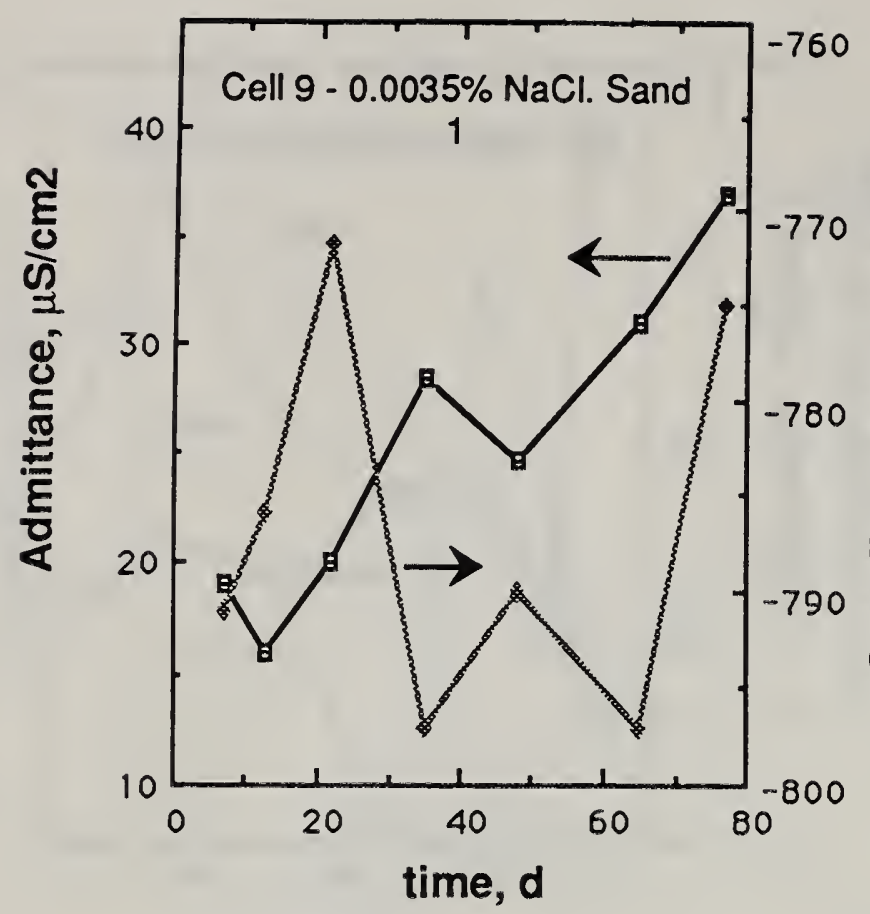

a)

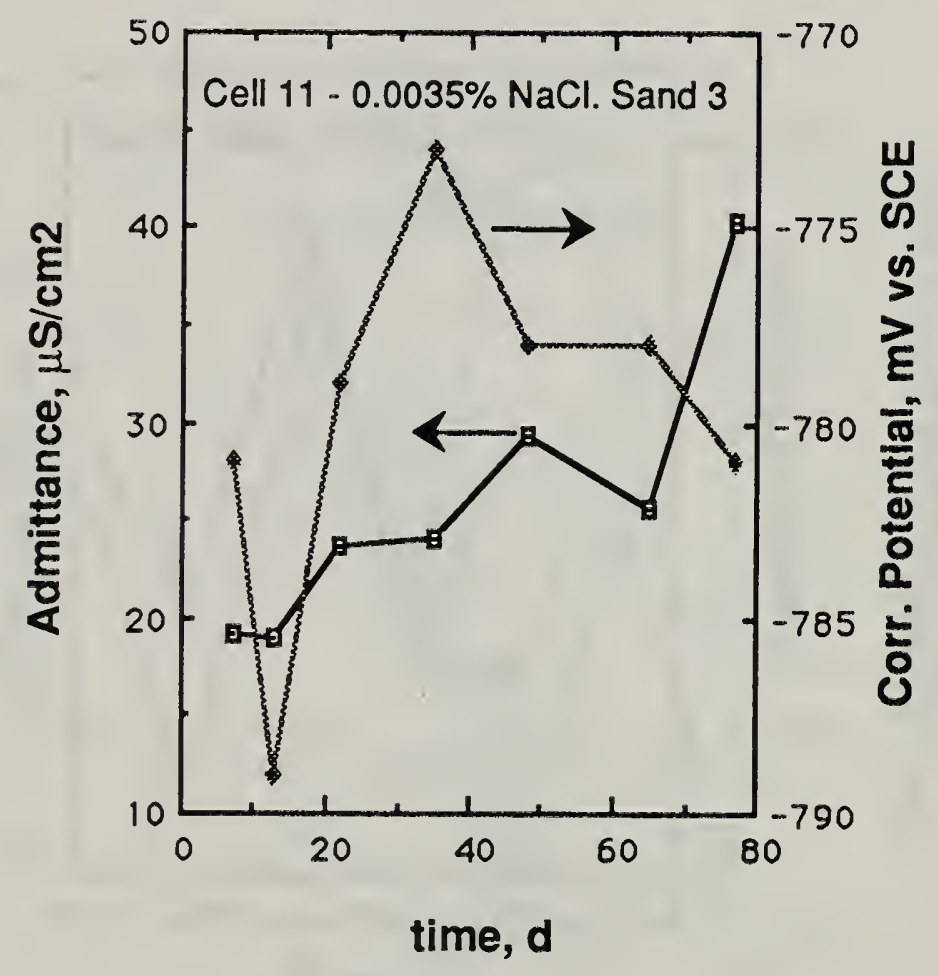

c)

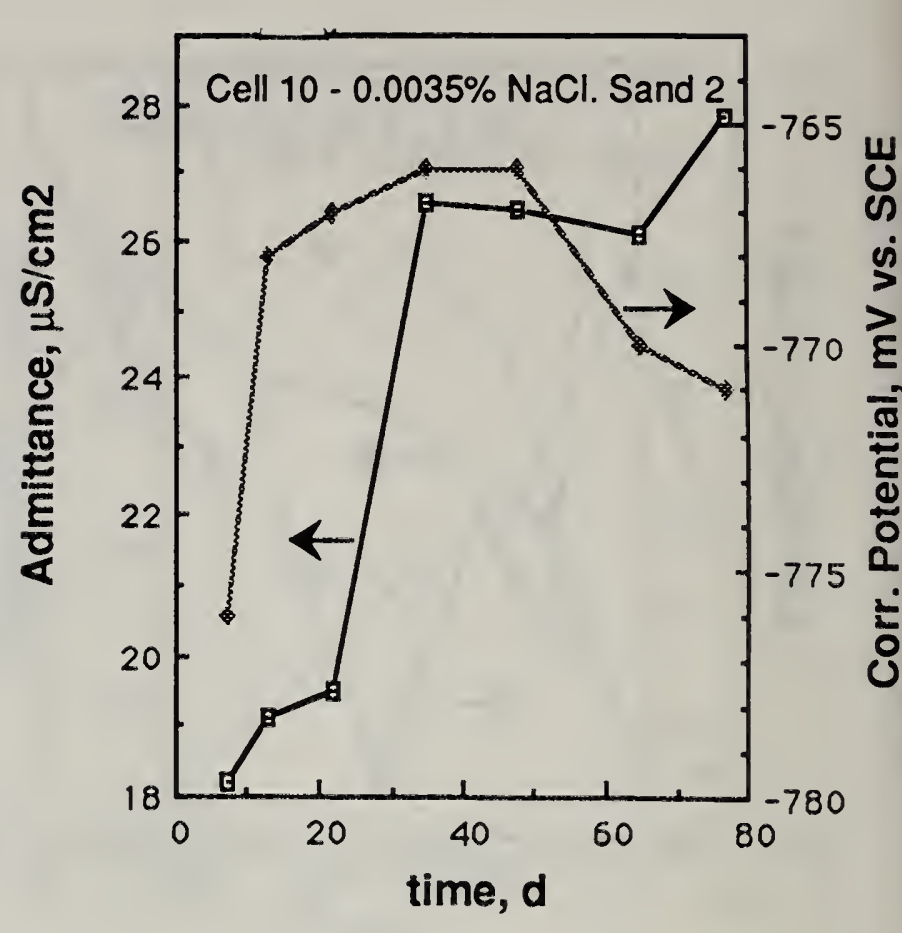

b)

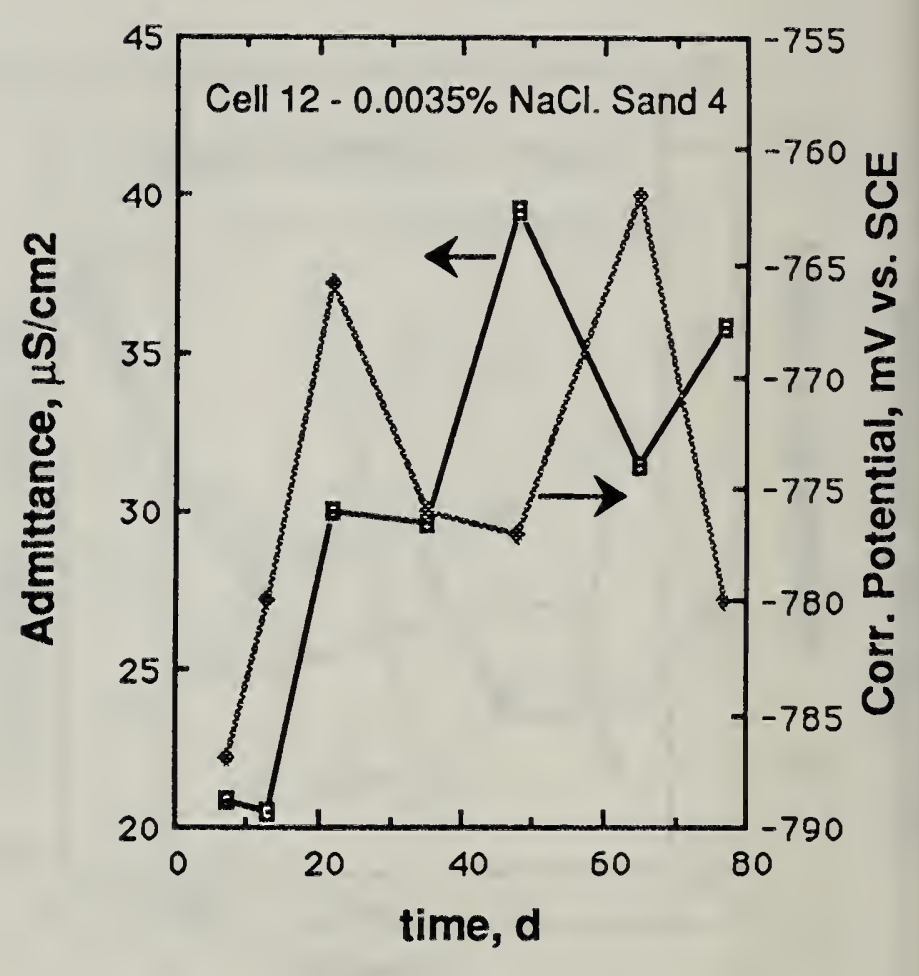

d)

Fig. 12. Measured Electrode Admittance and Corrosion Potential. Cells $9,10,11$, and 12 


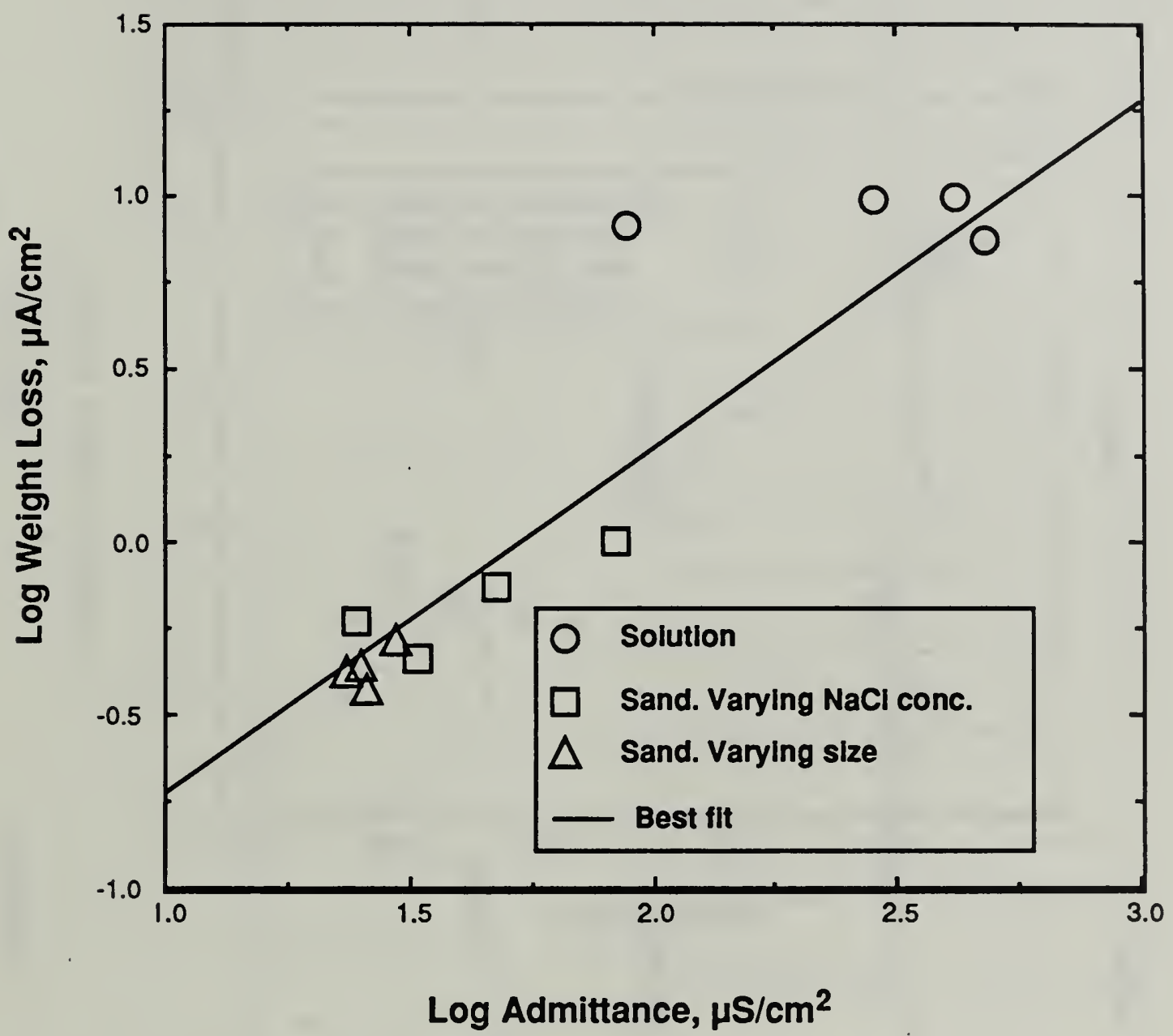

Fig. 13. Comparison between weight loss data and EIS data 


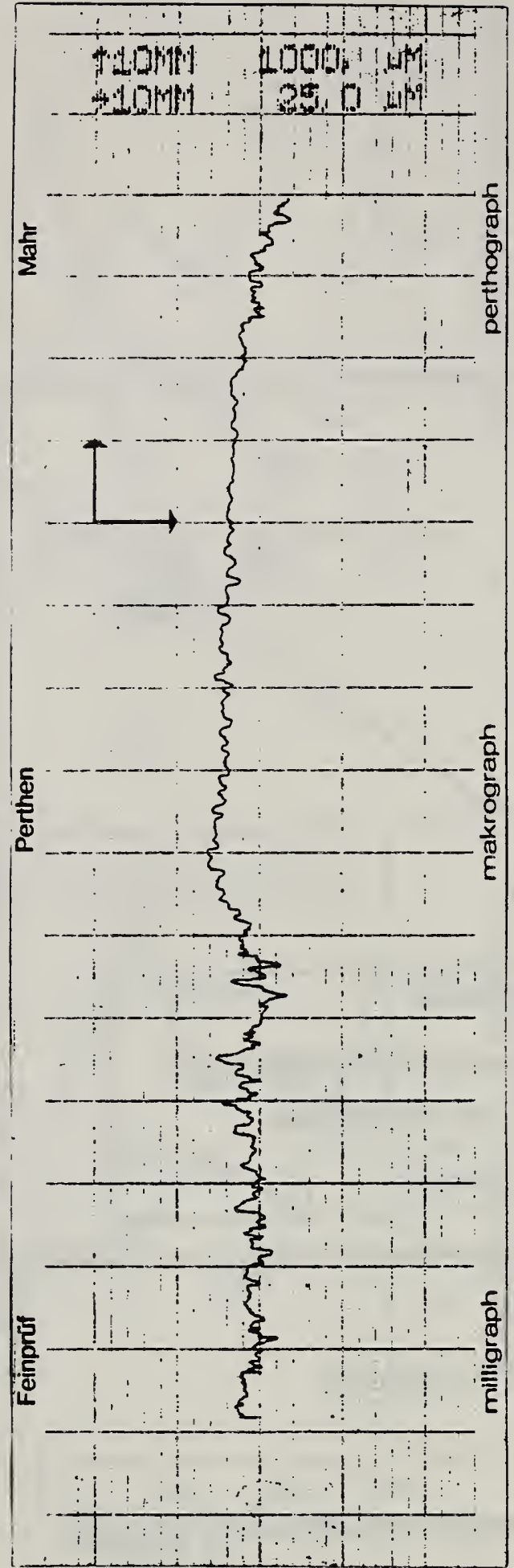

0)

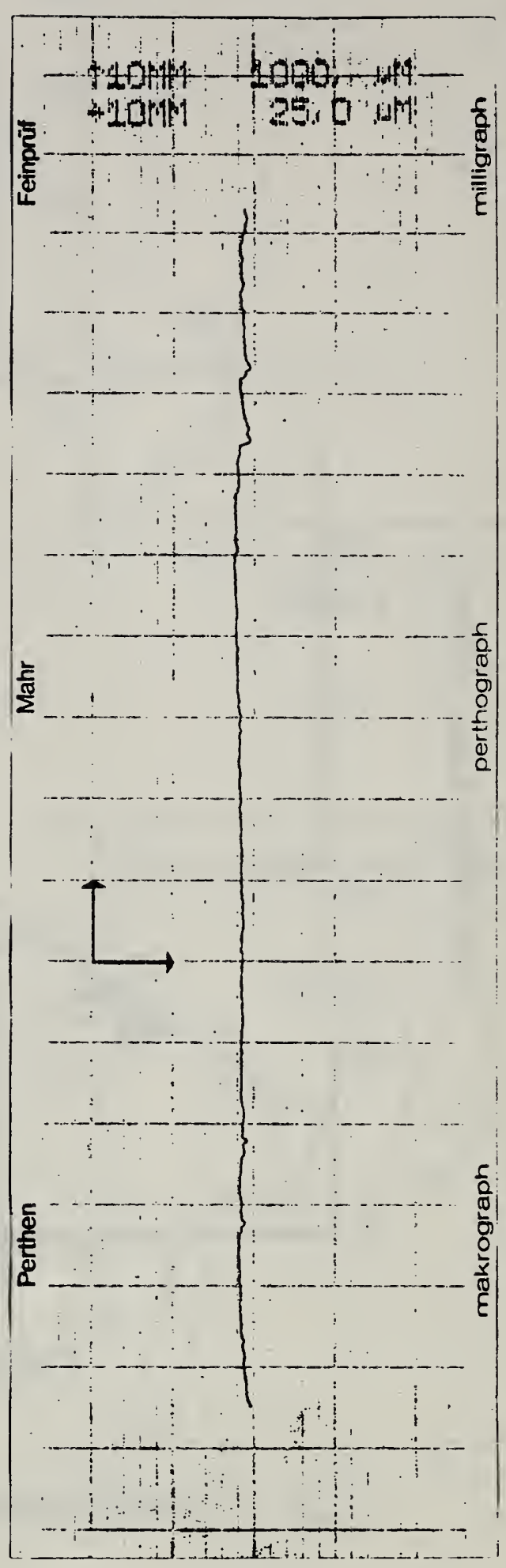

b)

Fig. 14. Examples of Profilometer Traces.

a) $035 \% \mathrm{NaCl}$ Solution

b) $3.5 \% \mathrm{NaCl}$ Solution in Sond 


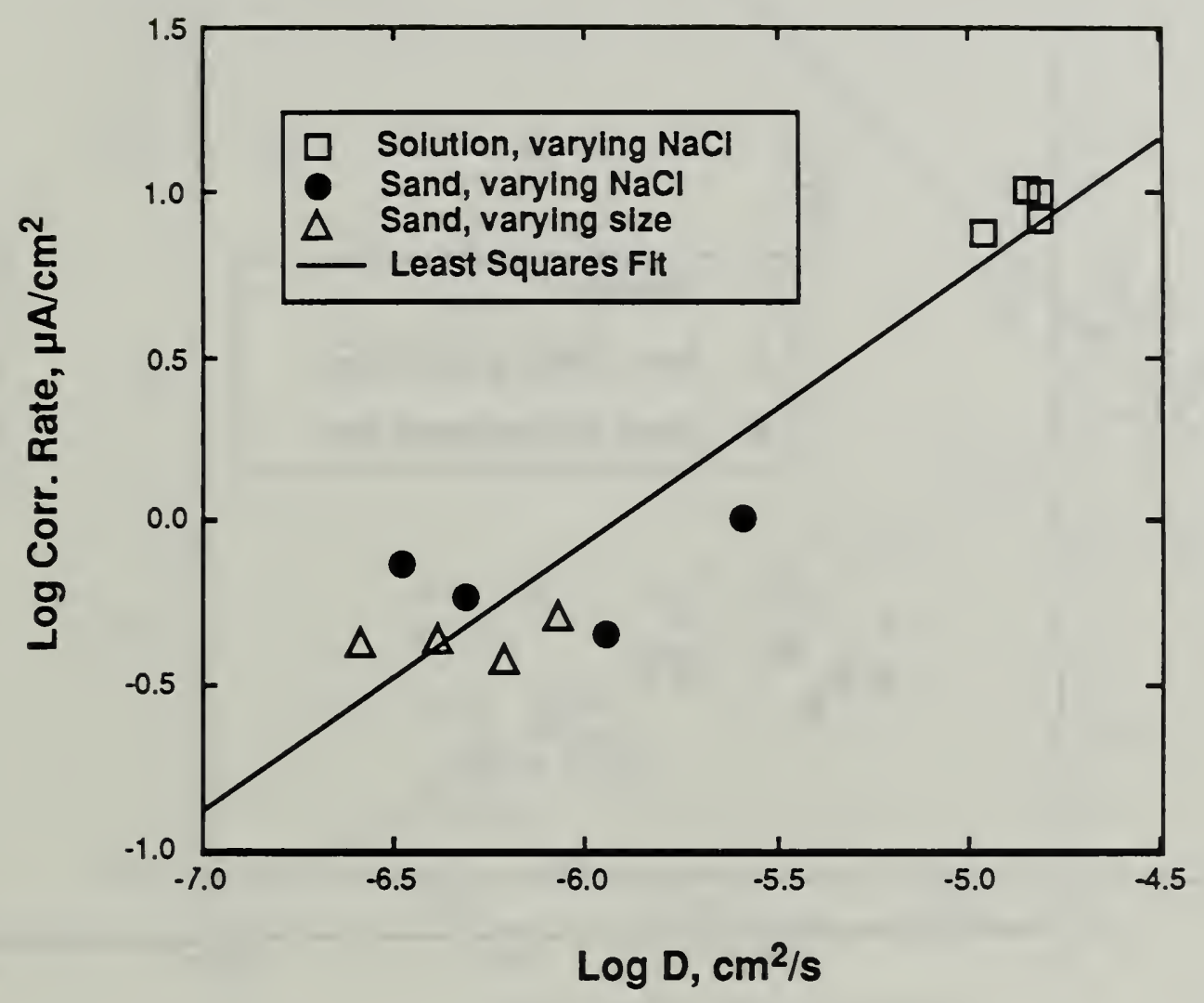

Fig. 15. Corrosion rate vs. effective diffusion coefficient in the medium 


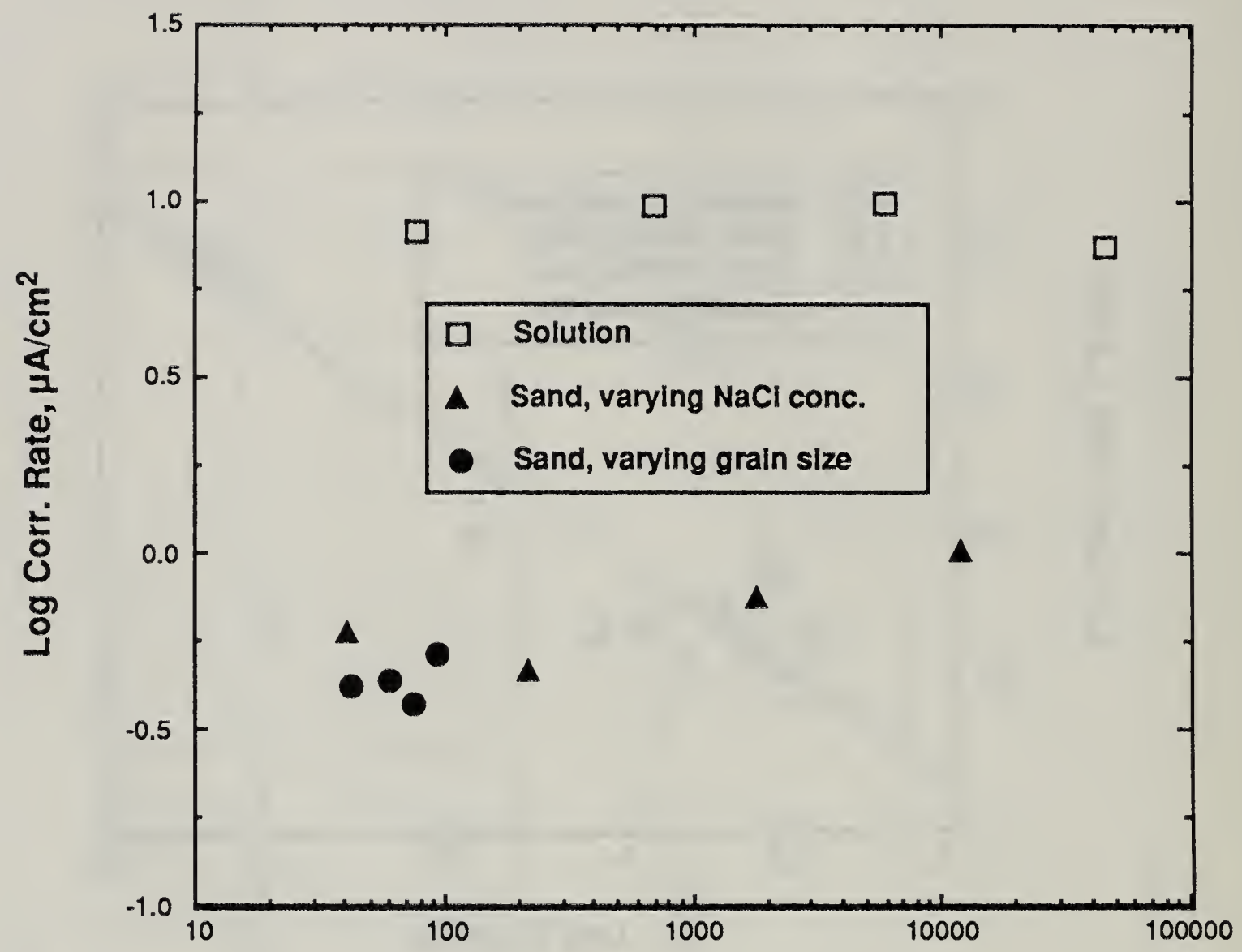

Conductivity, $\mu \mathrm{S} / \mathrm{cm}$

Fig. 16. Corrosion rate vs. conductivity of the medium 


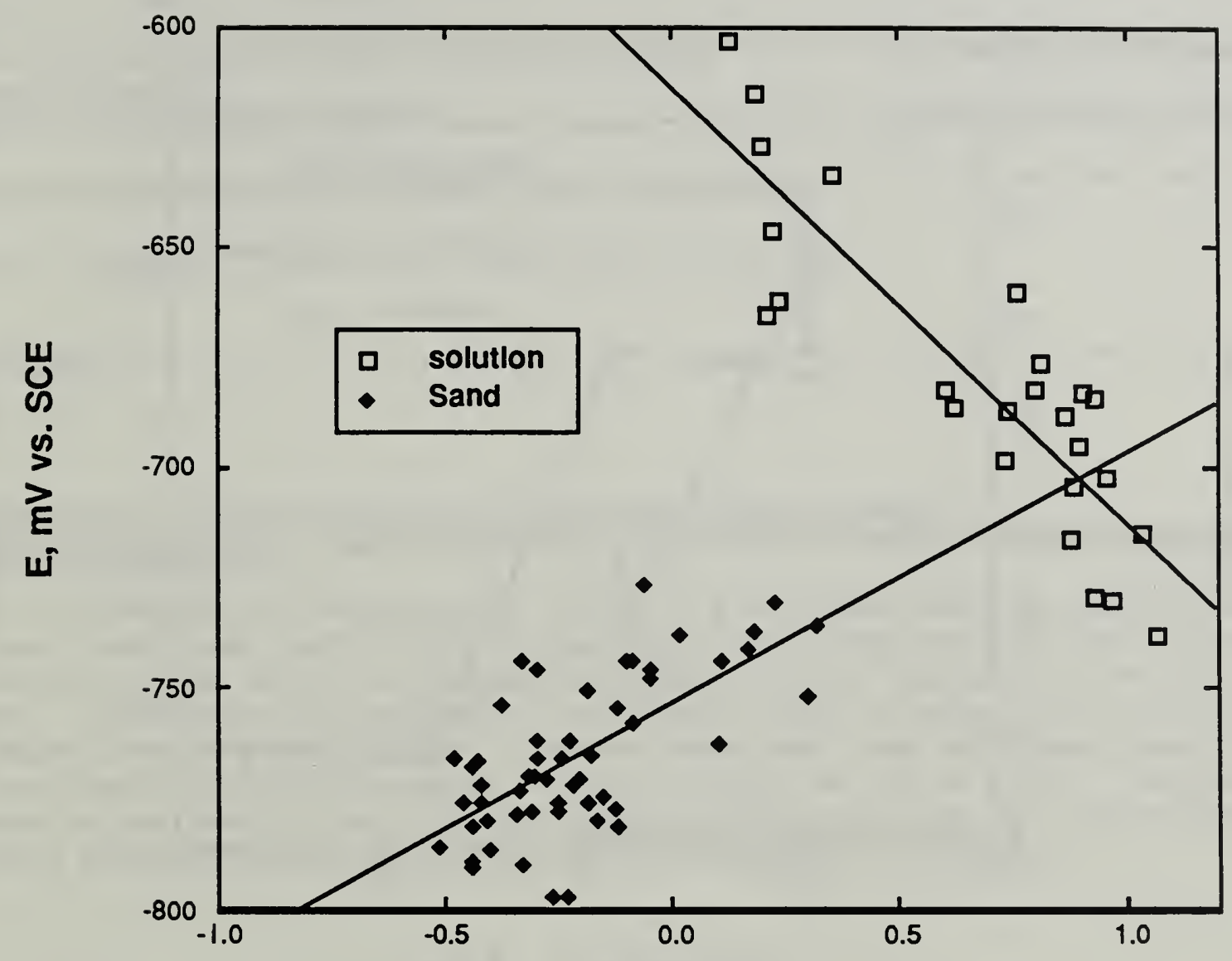

Log Curr. Density, $\mu \mathrm{A} / \mathrm{cm}^{2}$

Fig. 17. Relationship between corrosion rate and corrosion potential in aqueous solution and in sand 


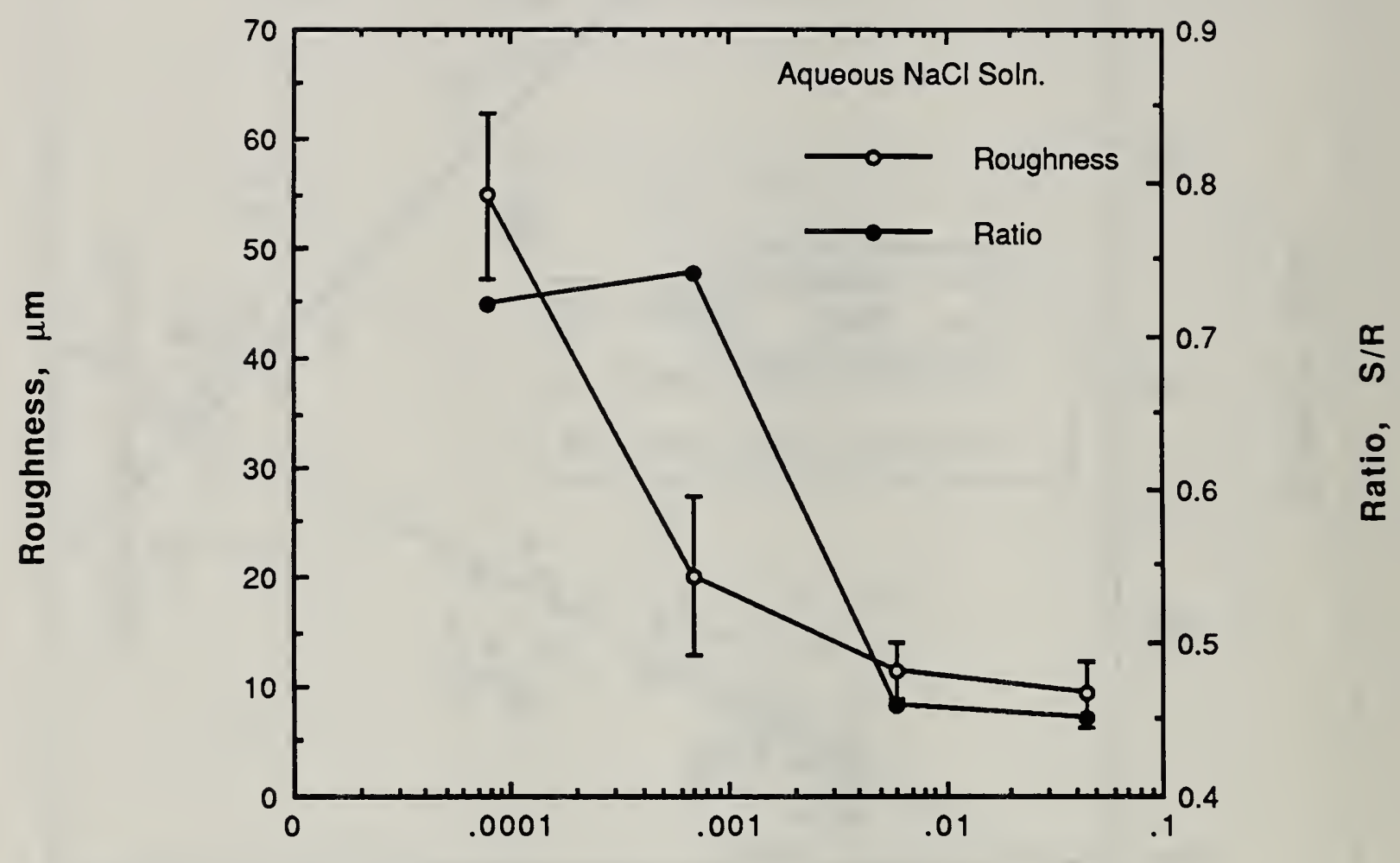

Conductivity, $\quad 5 / \mathrm{cm}$

Fig. 18. Small and Large Scale Surface Roughness as a Function of Solution Conductivity. 


\section{BIBLIOGRAPHIC DATA SHEET}

4. TILEAD SUOTITE

3 MULUCATION DATE

SEPTEMBER 1990

Effect of Oxygen Transport and Resistivity of the Environment on the Corrosion of Steel

5. AUTHOn(S)

E. Escalante, T. Oka, U. Bertocci

Q PEAFONMINO ORQANIZATION (IF JOINT OR OTHER THAN NIST, SEE INSTRUCTIONS)

U.S. DEPARTMETT OF COMMERCE MTTOML MSTITUTE OF STANDARDS AND TECHNOLOOY CWTHERSEURG, MD 20099

7. CONTMCT/ORANT HUMBER

Q. TYPE OF REPORT AND PERIOD COVERED

9. SPONSORING ORCANIZATION MAME AND COMPLETE ADDRESS (STREET, CTY, STATE, ZUP)

U.S. Nuclear Regulatory Commission, Washington, DC 20555

10. SUPPLMETTAYNOTES

DOCUMETT DESCRIBES A COMPUTER PROQRAM; SF-185, FIPS SOFTWARE SUMMATY, IS ATTACHED.

11. ABSTRACT (A 200-WOAD OR LESS FACTUAL SUMMAAY OF MOST SIONIFCANT INFORMATIOH. FOCUMENT INCWUDES A SIONIFCAYT BUUOQRAPY OR UTERATURE SUPVEY, MENTION TT HERE)

This study is directed at investigating the rate of corrosion and its spatial distribution, th develop under conditions where transport of oxygen and conductivity of the environment are controlled over a wide range, including low conductivity as expected in the Yucca Mountain environment. The results indicate that the corrosion rate of steel is directly related to the rate of oxygen transport over several orders of magnitude, and increasing conductivity by one order of magnitude increases corrosion rate by a factor of two or three. Of greater significance is the result that indicates that as conductivity of the environment decreases, and corrosion rate decreases, the degree of localized attack increases.

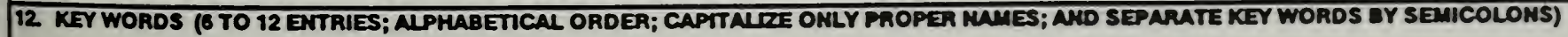
corrosion of steel, environment resistivity, localized.corrosion.oxygen transport, simulated soil, uniform corrosion.

12.

UNUMrTED

FON OFFCUL DISTRIBUTION, DO NOT RELEASE TO MATONAL TECHMCNL MFORMATION SERMCE (NTTS).

ORDER FROM SUPERINTENDENT OF DOCUMENTS, U.S. COVERMMENT PANTHWO OFFCE, WASHMUOTOM, DC 20102

ORDER PROM MATIOMAL TECHMICAL INFORMATION SERVCE (NIS), SPRWOFIED, VA 22101.
14. MULLEN OF PRINTED PAQES

38

15. PNCE

$\mathrm{AO3}$ 


